\title{
Air mass physiochemical characteristics over New Delhi: impacts on aerosol hygroscopicity and cloud condensation nuclei $(\mathrm{CCN})$ formation
}

\author{
Zainab Arub ${ }^{1}$, Sahil Bhandari ${ }^{2}$, Shahzad Gani ${ }^{3}$, Joshua S. Apte ${ }^{3}$, Lea Hildebrandt Ruiz ${ }^{2}$, and Gazala Habib ${ }^{1}$ \\ ${ }^{1}$ Department of Civil Engineering, Indian Institute of Technology Delhi, New Delhi, India \\ ${ }^{2}$ McKetta Department of Chemical Engineering, The University of Texas at Austin, Austin, Texas, USA \\ ${ }^{3}$ Department of Civil, Architectural and Environmental Engineering, The University of Texas at Austin, Austin, Texas, USA
}

Correspondence: Zainab Arub (jyotika.mmmec@gmail.com)

Received: 11 November 2019 - Discussion started: 3 December 2019

Revised: 12 April 2020 - Accepted: 16 April 2020 - Published: 12 June 2020

\begin{abstract}
Delhi is a megacity subject to high local anthropogenic emissions and long-range transport of pollutants. This work presents for the first time time-resolved estimates of hygroscopicity parameter $(\kappa)$ and cloud condensation nuclei $(\mathrm{CCN})$, spanning for more than a year, derived from chemical composition and size distribution data. As a part of the Delhi Aerosol Supersite (DAS) campaign, the characterization of aerosol composition and size distribution was conducted from January 2017 to March 2018. Air masses originating from the Arabian Sea (AS), Bay of Bengal (BB), and southern Asia (SA) exhibited distinct characteristics of timeresolved sub-micron non-refractory $\mathrm{PM}_{1}\left(\mathrm{NRPM}_{1}\right)$ species, size distributions, and CCN number concentrations. The SA air mass had the highest $\mathrm{NRPM}_{1}$ loading with high chloride and organics, followed by the $\mathrm{BB}$ air mass, which was more contaminated than AS, with a higher organic fraction and nitrate. The primary sources were identified as biomassburning, thermal power plant emissions, industrial emissions, and vehicular emissions. The average hygroscopicity parameter $(\kappa)$, calculated by the mixing rule, was approximately 0.3 (varying between 0.13 and 0.77 ) for all the air masses $(0.32 \pm$ 0.06 for $\mathrm{AS}, 0.31 \pm 0.06$ for $\mathrm{BB}$, and $0.32 \pm 0.10$ for $\mathrm{SA}$ ). The diurnal variations in $\kappa$ were impacted by the chemical properties and thus source activities. The total, Aitken, and accumulation mode number concentrations were higher for SA, followed by BB and AS. The mean values of estimated CCN number concentration $\left(N_{\mathrm{CCN}} ; 3669-28926 \mathrm{~cm}^{-3}\right)$ and the activated fraction $\left(a_{\mathrm{f}} ; 0.19-0.87\right)$, for supersaturations varying from $0.1 \%$ to $0.8 \%$, also showed the same trend, implying that these were highest in SA, followed by those in BB
\end{abstract}

and then those in AS. The size turned out to be more important than chemical composition directly, and the $N_{\mathrm{CCN}}$ was governed by either the Aitken or accumulation modes, depending upon the supersaturation (SS) and critical diameter $\left(D_{\mathrm{c}}\right) . a_{\mathrm{f}}$ was governed mainly by the geometric mean diameter (GMD), and such a high $a_{\mathrm{f}}(0.71 \pm 0.14$ for the most dominant sub-branch of the SA air mass - R1 - at $0.4 \%$ SS) has not been seen anywhere in the world for a continental site. The high $a_{\mathrm{f}}$ was a consequence of very low $D_{\mathrm{c}}(25-130 \mathrm{~nm}$, for SS ranging from $0.1 \%$ to $0.8 \%$ ) observed for Delhi. Indirectly, the chemical properties also impacted CCN and $a_{\mathrm{f}}$ by impacting the diurnal patterns of Aitken and accumulation modes, $\kappa$ and $D_{\mathrm{c}}$. The high-hygroscopic nature of aerosols, high $N_{\mathrm{CCN}}$, and high $a_{\mathrm{f}}$ can severely impact the precipitation patterns of the Indian monsoon in Delhi, impact the radiation budget, and have indirect effects and need to be investigated to quantify this impact.

\section{Introduction}

High aerosol loading can have huge climatic repercussions on precipitation including land surface feedback through rainfall, surface energy budget, and variation in latent heat atmospheric influx (Tao et al., 2012). Added cloud condensation nuclei $(\mathrm{CCN})$ may nucleate a larger number of smaller droplets, which then take a longer time to coalesce into raindrops (Gunn and Phillips, 1957; Squires, 1958). A greater cloud depth, indicating higher rain initiation, occurs in more 
polluted clouds. Complete suppression of warm rain might also occur and get aggravated due to additional CCN activation above the cloud base (Braga et al., 2017). While rain suppression was observed in the case of polluted urban and industrial plumes (Rosenfeld, 2000), and smoke arising from forest fires (Rosenfeld, 1999), the precipitation tendency increases due to influx of giant CCN consisting of sea salt (Rosenfeld et al., 2002) and salt playas (Rudich et al., 2002) due to acceleration of the auto-conversion rate (Rosenfeld et al., 2008). To understand the impact of pollution on indirect radiative forcing and precipitation in highly polluted regions, the information on $\mathrm{CCN}$ number concentration is essential in global climate models (GCMs) and regional climate models (RCMs).

As per the fifth IPCC report (Boucher et al., 2013), the two most important factors governing $\mathrm{CCN}$ activation and number concentration are size and composition. The aerosol chemical composition impacts the aerosol hygroscopicity, which impacts the critical diameter and hence CCN activation. The hygroscopicity parameter $(\kappa)$ is defined as the total water uptake ability of aerosols (Petters and Kredenweis, 2007). Further, the increase in relative humidity (RH) due to water uptake by aerosol can impact visibility (Lee et al., 2016; Liu et al., 2012); secondary particle formation (Ervens et al., 2011); and measurements of remote sensing (Wang and Martin, 2007; Brock et al., 2016), aerosol loading, and its chemical composition (Chen et al., 2018). Hence, it is essential to determine the hygroscopicity of aerosols, especially in the polluted regions of the world, where these impacts are expected to be highly significant.

Although the recent precipitation data during 1950-2011, averaged over July and August for Delhi, reveal a significant decreasing trend, there has been an increasing trend in the frequency of heavy rainfall events and a decrease in the frequency of wet and rainy days when it rains for a shorter period (Guhathakurta et al., 2015). These occurrences are most likely signatures of aerosols impacting the cloud-nucleating properties, which calls for detailed $\mathrm{CCN}$ data examination. The high uncertainties associated with radiative forcings, both direct and indirect, especially at the regional level, are a result of poor representation of the aerosol distributions in GCMs. This is critical for the Indian sub-continent, where the variability in aerosol microphysical properties is very high, at various spatial and temporal scales. These necessitate the measurement of long-term aerosol physiochemical properties, the hygroscopicity parameter, and CCN estimates. Detailed CCN and $\kappa$ measurements have been carried out in different parts of the world (Rissler et al., 2004; Bougiatioti et al., 2011; Engelhart et al., 2012) and in India, in places like Kanpur (Bhattu and Tripathi, 2014, 2015; Ram et al., 2014), Mahabaleshwar (Leena et al., 2016), and the eastern Himalayas (Roy et al., 2017). However, no CCN measurements or estimates have been developed so far for Delhi. There is only one study that has estimated aerosol hygroscop- icity based on $\mathrm{PM}_{2.5}$ mass, $\mathrm{RH}$, and visibility data (Wang and Chen, 2019).

In this work, for the first time for Delhi, time-resolved size distribution and chemical speciation measurements were carried out from 15 January 2017 to 31 March 2018 as a part of the Delhi Aerosol Supersite (DAS) campaign (Gani et al., 2019). The time-resolved hygroscopicity parameter and $\mathrm{CCN}$ estimates were derived using chemical speciation data from an aerosol chemical speciation monitor (ACSM), and number concentration data from a scanning mobility particle sizer (SMPS), measured from January 2017 to March 2018. Data were analysed to investigate the following hypotheses: (a) the precursors to secondary organic aerosol (SOA) formation critically impact the chemical composition over Delhi, (b) the emission sources significantly impact $\mathrm{CCN}$ formation by governing the size distributions and chemical composition, and thus hygroscopicity, and (c) physical properties impact $\mathrm{CCN}$ more compared to chemical properties directly however, the physical properties are, in turn, shaped by the chemical properties.

\section{Methodology and instrumentation}

\subsection{Instrumentation}

For a detailed assessment of aerosol physiochemical properties, an SMPS (TSI, Shoreview, MN), ACSM (Aerodyne Research, Billerica MA), and aethalometer (Magee Scientific Model AE33, Berkeley, CA) were operated at the Indian Institute of Technology (IIT) Delhi in Block 5, at a height of nearly $15 \mathrm{~m}$, as a part of the DAS campaign. This sampling site in New Delhi was free from any source activity, except for a road, located $150 \mathrm{~m}$ away. The IIT campus is cleaner than the rest of the city. However, it lies in the heart of the city, and the outskirts of the campus experience fresh traffic influx. The IIT campus allows only limited access to vehicles and therefore has less traffic compared to the city in general. A temperature-controlled room was used to carry out the measurements. Two separate and thermally insulated sampling lines ( $3 / 4 \mathrm{in}$. outer-diameter stainless-steel tubes) with flows of 3 and $2 \mathrm{~L} \mathrm{~min}^{-1}$ equipped with $\mathrm{PM}_{1}$ cyclone, in line with a water trap and a Nafion membrane diffusion dryer (Magee Scientific Sample Stream Dryer, Berkeley, CA), were used for (1) an SMPS and ACSM in conjunction with a flow controller and (2) an aethalometer, respectively. A brief description of the instruments is given below. A detailed description of the instruments is given in Gani et al. (2019) and Bhandari et al. (2020).

The SMPS was comprised of a differential mobility analyser (DMA; TSI 3081), an electrostatic classifier (TSI 3080), an X-ray aerosol neutralizer (TSI 3088), and a water-based condensation particle counter (CPC; TSI 3785). The ambient air was sampled in the size range $12-560 \mathrm{~nm}$, with a time difference of $135 \mathrm{~s}$ between two scans. The sheath-to-aerosol 
flow ratio was $4: 1$, and the total flow drawn by the CPC was $1 \mathrm{~L} \mathrm{~min}^{-1}$. The two dominant modes (Aitken and accumulation) are well captured within this size range. The ACSM sampled the inlet air at a flow rate of $0.1 \mathrm{~L} \mathrm{~min}^{-1}$ with a time resolution of $\sim 1 \mathrm{~min}$. The calibration procedures and data processing are discussed in Gani et al. (2019). The ACSM collected time-resolved $\mathrm{NRPM}_{1}$ (non-refractory $\mathrm{PM}_{1}$ ) based on species that volatilize by $600^{\circ} \mathrm{C}$ and included $\mathrm{NO}_{3}^{-}, \mathrm{Cl}^{-}$, $\mathrm{SO}_{4}^{2-}, \mathrm{NH}_{4}^{+}$, and organics.

\subsection{Qualitative separation of organic aerosols as BBOA, HOA, and OOA}

The composition data presented in this work were collected in the DAS study. PMF (positive matrix factorization) analysis was conducted on the 15 months in the dataset. As a result, biomass-burning organic aerosol (BBOA) could be resolved as a separate factor only in spring 2018. This inability to resolve primary organic aerosol (POA) to separate factors, namely hydrocarbon-like organic aerosol (HOA) and BBOA, was attributed to the unit mass resolution of the instrument (Bhandari et al., 2020, and references therein). Owing to the lack of explicit BBOA and HOA separation in all seasons, the $\mathrm{Ng}$ et al. (2010) compilation of profiles was analysed, combined with the profiles identified in spring in Delhi. It was observed that spring 2018 profiles fell within the bounds of the uncertainty of the $\mathrm{Ng}$ et al. (2010) compilation. Thus, $\mathrm{Ng}$ et al. (2010) reference profiles were utilized for source attribution of each cluster. While factor profiles can differ across the world, taking regionally relevant profiles together with those usually employed as reference profiles for PMF analysis likely accounts for this variability. As a part of the analysis conducted here, the mean strength at the relevant $\mathrm{m} / \mathrm{z}$ (s) $(m / z 57$ and 60) and the standard deviation (SD) of the profiles at these $m / z$ (s) were utilized in the analysis.

Organic aerosols were qualitatively segregated by comparing the $\mathrm{m} / \mathrm{z}$ ratios of $f_{57}$ and $f_{60}$ with the reference profiles of BBOA $\left(f_{57}: 0.0337 \pm 0.00884, f_{60}: 0.025 \pm 0.00521\right)$, HOA $\left(f_{57}: 0.0838 \pm 0.00378, f_{60}: 0.00227 \pm 0.00214\right)$, and oxygenated organic aerosol (OOA) $\left(f_{57}: 0.00997 \pm 0.00786\right.$, $\left.f_{60}: 0.00571 \pm 0.00349\right)$, as reported by $\mathrm{Ng}$ et al. (2010). This was done by first calculating the cluster means of $f_{57}$ and $f_{60}$ for each cluster (Table 2). This was followed by an evaluation of residuals. Residuals represent the deviation of the cluster means from the reference profiles. The HOA, BBOA, and OOA residuals ( $R_{\mathrm{HOA}}, R_{\mathrm{BBOA}}$, and $\left.R_{\mathrm{OOA}}\right)$ were then calculated based on cluster means of $f_{57}$ and $f_{60}\left(\mathrm{CM}_{f_{57}}\right.$ and $\mathrm{CM}_{f_{60}}$ ), with respect to the corresponding means of reference profiles $\left(\mathrm{RM}_{f_{57}}\right.$ and $\left.\mathrm{RM} \mathrm{f}_{60}\right)$, as given below for HOA in Eq. (1):

$$
R_{\mathrm{HOA}}=\frac{\sqrt{\left(\mathrm{CM}_{f_{57} \mathrm{HOA}}-\mathrm{RM}_{f_{57} \mathrm{HOA}}\right)^{2}}}{+\left(\mathrm{CM}_{f_{60} \mathrm{HOA}}-\mathrm{RM}_{\left.f_{60} \mathrm{HOA}_{1}\right)^{2}}\right.} .
$$

The reference residuals for HOA, BBOA, and OOA ( $\left.R_{\text {Ref_HOA }}, R_{\text {Ref_BBOA }}, R_{\text {Ref_OOA }}\right)$ were then calculated using standard deviations of reference profiles $\left(\mathrm{SD}_{f_{57} \_ \text {Ref_HOA, }}\right.$ $\left.\mathrm{SD}_{f_{57} \text { Ref_BBOA }}, \mathrm{SD}_{f_{57} \text { Ref_OOA }}\right)$, as given below for HOA in Eq. (2):

$$
R_{\text {Ref_HOA }}=\sqrt{\left(\mathrm{SD}_{f_{57} \_ \text {Ref_HOA }}\right)^{2}+\left(\mathrm{SD}_{f_{60 \_} \text {Ref_HOA }}\right)^{2}} .
$$

The residuals of the cluster means were then compared with the reference residuals as per the six conditions described in detail in Sect. S1 in the Supplement and classified as HOA, BBOA, OOA, or mixed.

\subsection{Estimation of $\kappa$ and $\mathrm{CCN}$}

The ACSM data were used to calculate $\kappa$ as per the following mixing rule in Eq. (3) (Petters and Kredenweis, 2007):

$\kappa=\sum_{i} \epsilon_{i} \kappa_{i}$

where $\epsilon_{i}$ and $\kappa_{i}$ represent the volume fractions and individual hygroscopicity parameters of the various components. The inorganics were represented by $\left(\mathrm{NH}_{4}\right)_{2} \mathrm{SO}_{4}, \mathrm{NH}_{4} \mathrm{Cl}$, and $\mathrm{NH}_{4} \mathrm{NO}_{3}$. The organic $\kappa_{i}$ was taken as 0.1 (Gunthe et al., 2009, 2011; Dusek et al., 2010; Rose et al., 2011). $\kappa_{i}$ values were taken as 0.61 for $\left(\mathrm{NH}_{4}\right)_{2} \mathrm{SO}_{4}, 1.02$ for $\mathrm{NH}_{4} \mathrm{Cl}$, and 0.67 for $\mathrm{NH}_{4} \mathrm{NO}_{3}$ (Sullivan et al., 2009; Petters and Kredenweis, 2007). The density values to estimate the volume fraction of the inorganic constituents were taken as $1770 \mathrm{~kg} \mathrm{~m}^{-3}$ for $\left(\mathrm{NH}_{4}\right)_{2} \mathrm{SO}_{4}, 1519 \mathrm{~kg} \mathrm{~m}^{-3}$ for $\mathrm{NH}_{4} \mathrm{Cl}$, and $1720 \mathrm{~kg} \mathrm{~m}^{-3}$ for $\mathrm{NH}_{4} \mathrm{NO}_{3}$ (Haynes et al., 2014). The density of organics was taken as $1500 \mathrm{~kg} \mathrm{~m}^{-3}$ (Bougiatioti et al., 2009). $\kappa$ for BC was taken as zero, as reported in several studies (Hong et al., 2014; Leng et al., 2014; Wu et al., 2013).

It should be noted that we assumed that the $\kappa$ calculated from $\mathrm{NRPM}_{1}$ data of ACSM represents the bulk hygroscopicity parameter in the absence of size-resolved measurements and is a limitation of this work. The difference due to the assumption cannot be accounted for and should be investigated in the future. However, it is reported that for $\kappa>0.1, \mathrm{CCN}$ closures within $20 \%$ can be achieved assuming bulk composition and internal mixing (Wang et al., 2010). Temperature, relative humidity $(\mathrm{RH})$, and the calculated $\kappa$ were then used to calculate the critical diameter $\left(D_{\mathrm{c}}\right)$ from the multicomponent $\kappa$-Köhler theory (Bhattu and Tripathi, 2015). The temperature and $\mathrm{RH}$ data are available from the RK Puram site ( 3-4 km aerial distance from the measurement site) maintained by the Central Pollution Control Board (CPCB), India. $N_{\mathrm{CCN}}$ was then estimated by integrating the size distribution obtained from SMPS above $D_{\mathrm{c}}$. The CCN estimates were obtained for the supersaturation (SS) of $0.1 \%$, $0.15 \%, 0.2 \%, 0.35 \%, 0.4 \%, 0.5 \%, 0.6 \%, 0.7 \%, 0.75 \%$, $0.8 \%, 0.85 \%$, and $1 \%$. However, for the sake of detailed analysis, $0.1 \%, 0.4 \%$, and $0.8 \%$ were chosen: $0.1 \%$ represents the condition when the effect of chemical composi- 
tion is expected to be the highest, $0.4 \%$ represents the condition for convective clouds, and $0.8 \%$ represents a highsupersaturation state, when almost all aerosols tend to get activated as $\mathrm{CCN}$.

\subsection{Air mass characterization}

To characterize the air masses, the Hybrid Single Particle Lagrangian Integrated Trajectory (HYSPLIT) model was used (Draxler and Rolph, 2003) to determine the major pathways of aerosols reaching Delhi. The $5 \mathrm{~d}$ back-trajectory analysis was done at the receptor site at a height of $500 \mathrm{~m}$. The cluster analysis was then performed seasonally to identify the cluster mean trajectories per season. These mean trajectories were then again re-clustered to identify three main clusters based on the directions of the mean cluster trajectories: the Arabian Sea (AS) branch (16.5\% of total trajectories), the Bay of Bengal (BB) branch (13\% of total trajectories), and the southern Asian (SA) branch (70.5\% of total trajectories). The BB branch was further classified as B (54\%) and B.reg ( $45 \%$ ), where B represents the air masses reaching the sea, while B.reg represents the air masses that aligned towards reaching the Bay of Bengal but did not hit the sea. The SA branch was partitioned into L (17.5\%), R1 (54\%), R2 $(18 \%)$, and R3 (11\%). L represents the local trajectories originating within India, mainly from Delhi, Punjab, and Haryana. R1 represents trajectories coming from Pakistan and Afghanistan. R2 represents trajectories originating from Iran. R3 is representative of all trajectories beyond these, including a portion of South Africa, the Mediterranean Sea, and Turkey. The seasonal clusters for the winter, spring, summer, and monsoon of the year 2017 and winter and spring of the year 2018 are shown in Fig. S1 in the Supplement. The re-clustering is shown in Fig. 1. All the chemical speciation data from ACSM and size distribution data from SMPS were then categorized as per the classification discussed above and used in the following discussion.

\subsection{Aerosol ageing estimation}

The $\mathrm{NO}_{x}$, toluene, and benzene data inventory for the entire campaign was taken from the CPCB for RK Puram, whenever available. The data were not available for branch B. To determine the photochemical ageing of aerosols, toluene and benzene concentrations were used to calculate the life (in hours), as per Nault et al. (2018) in Eq. (4):

$$
\begin{aligned}
t & =-\frac{1}{[\mathrm{OH}] \times\left(k_{\text {toluene }}-k_{\text {benzene }}\right)} \\
& \times\left(\ln \left(\frac{\text { toluene }_{i}(t)}{\text { benzene }_{i}(t)}\right)-\ln \left(\frac{\text { toluene }_{i}(o)}{\text { benzene }_{i}(o)}\right)\right),
\end{aligned}
$$

where $[\mathrm{OH}]=1.5 \times 10^{6}$ molecules $\mathrm{cm}^{-3}$ (Nault et al., 2018), $k_{\text {toluene }}=2.3 \times 10^{-12} \exp (-190 / T)$, and $k_{\text {benzene }}=1.8 \times$ $10^{-12} \exp (340 / T)$ (Atkinson et al., 2006) are the rate constants for each aromatic compound, toluene ${ }_{i}(o)=1.85$ and benzene $_{i}(o)=2.31$. $[\mathrm{OH}]$ is not constant and varies considerably temporally and spatially, but due to the unavailability of data of its variation for Delhi, it was assumed constant for ageing calculation.

\section{Results and discussion}

The HYSPLIT analysis revealed that the north-western direction is the most dominant direction, which is representative of SA air masses, and within it, R1 is the most dominant, indicating that overall, the emissions from Pakistan and Afghanistan and the sources en route govern Delhi's aerosol characteristics. However, the chemical signatures were potentially different for the various clusters, which explains the variation in aerosol properties with time. Due to the different nature of sources and pathways, aerosol properties vary, resulting in different hygroscopic properties and $\mathrm{CCN}$ forming potential. These aspects are discussed in the following sections.

\subsection{Introduction to characteristics and sources of air masses}

Out of the three main branches, the SA branch was the most anthropogenically contaminated, followed by BB and AS branches, as indicated by the mean $\mathrm{NRPM}_{1}$ mass concentrations: $125.2 \pm 91.6,45.9 \pm 23.3$, and $32.5 \pm 20.6 \mu \mathrm{g} \mathrm{m}^{-3}$, respectively (Fig. 2a). The total $\mathrm{NRPM}_{1}$ loading for the SA branch followed the sequence: $\mathrm{NRPM}_{1(\mathrm{~L})}<\mathrm{NRPM}_{1(\mathrm{R} 3)}<$ $\mathrm{NRPM}_{1(\mathrm{R} 1)}<\mathrm{NRPM}_{1(\mathrm{R} 2)}$. Amongst the SA branches, L was associated with the lowest organic $\left(52.8 \pm 40.6 \mu \mathrm{g} \mathrm{m}^{-3}\right)$ and inorganic $\left(42.1 \pm 33.1 \mathrm{~g} \mathrm{~m}^{-3}\right)$ content, while R2 had the maximum organic $\left(85.4 \pm 59.8 \mu \mathrm{g} \mathrm{m}^{-3}\right)$ and inorganic $\left(57.9 \pm 47.5 \mu \mathrm{g} \mathrm{m}^{-3}\right)$ content. A summary of the overall characteristics is given in Table 1. The prominent sources for the SA air mass include metal processing industries (Haryana and Delhi NCR), coke and petroleum refining (Punjab), thermal power plants (Pakistan, Punjab, and NCR Delhi), agricultural-residue burning (Punjab and Haryana), soil dust (Pakistan, Punjab) (Jaiprakash et al., 2017), and coal mines in Pakistan, where non-ideal burning of $\left(\mathrm{NH}_{4}\right)_{2} \mathrm{SO}_{4}$ occurs (Chakraborty et al., 2015).

When comparing the BB branches, total $\mathrm{NRPM}_{1}$ for $\mathrm{B}$ $\left(41.9 \pm 20.8 \mu \mathrm{g} \mathrm{m}^{-3}\right)$ was slightly less than that for B.reg $\left(47.3 \pm 25.4 \mu \mathrm{g} \mathrm{m}^{-3}\right)$, and this can be attributed to the fact that the B.reg air mass does not travel over water (originates adjacent to the coastline) but is subject to its influence, while the B air mass travels over water and is therefore cleaner. B.reg had a slightly higher inorganic and organic content than that of B.

The relatively higher abundance of aerosols of BB over AS can be attributed to both the sources and the pathways of air masses. In terms of source, the Bay of Bengal is more anthropogenically impacted than the Arabian Sea, as concluded 


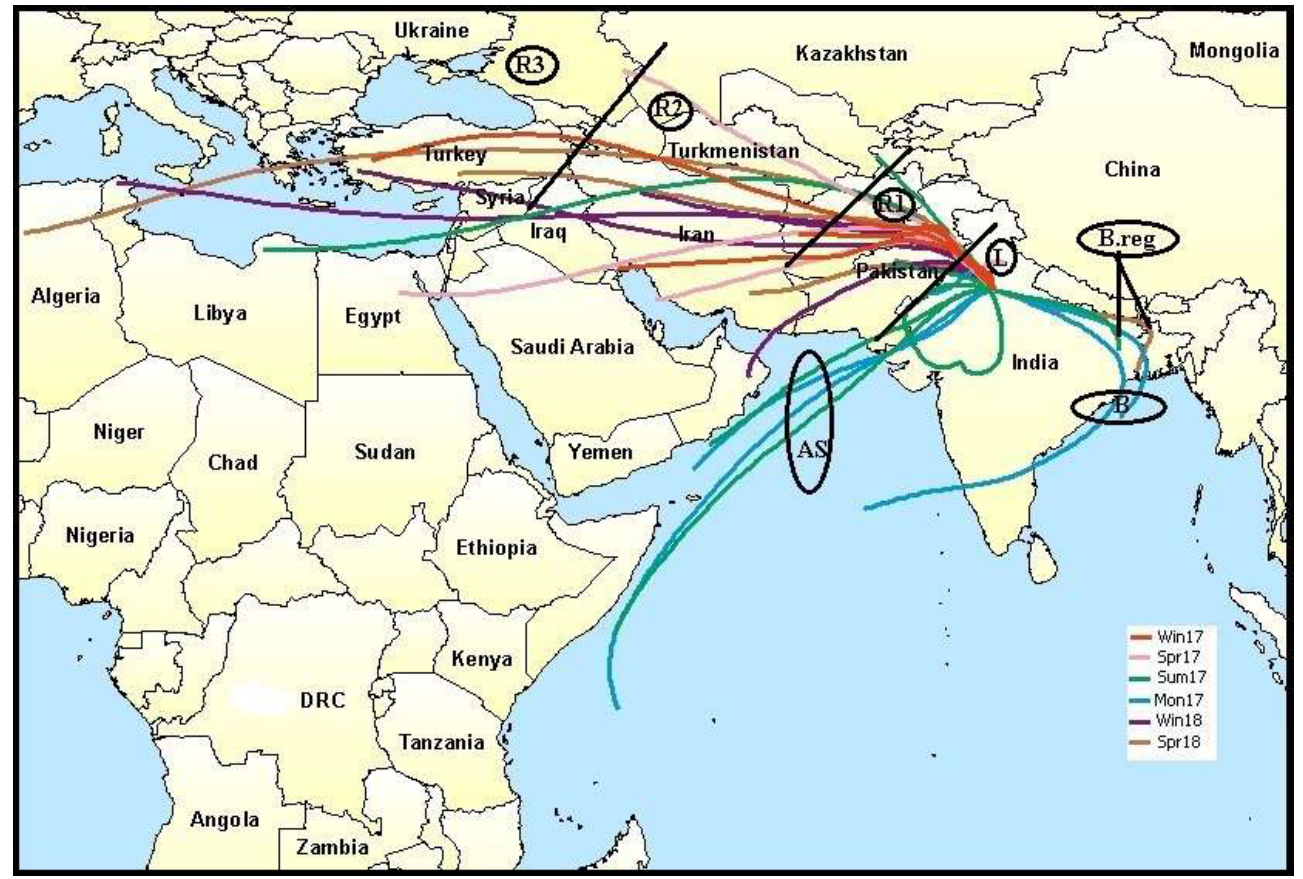

Figure 1. HYSPLIT grouping of cluster mean trajectories based on directions and distances of source regions. Cluster mean trajectories were obtained for all seasons and clubbed as per directions. AS branch originated from the Arabian Sea; BB branch, with sub-branches B and B.reg, originated from Bay of Bengal; and SA branch, with sub-branches L, R1, R2, and R3 from the north-western direction, originated mainly on the southern Asian landmass. The map layer used is from "World Countries (Generalized)", by Esri, Garmin International (2010, https://www.arcgis.com/home/item.html?id=170b5e6529064b8d9275168687880359, last access: 17 May 2020). (C Esri, Garmin. All rights reserved. This map is intellectual property of Esri, Garmin, and used under license. Further details may be found at https://www.esri.com (last access: 17 May 2020).

Table 1. Mean values of $\mathrm{NRPM}_{1}$ species and $\mathrm{BC}\left(\mu \mathrm{g} \mathrm{m}^{-3}\right)$ for all clusters.

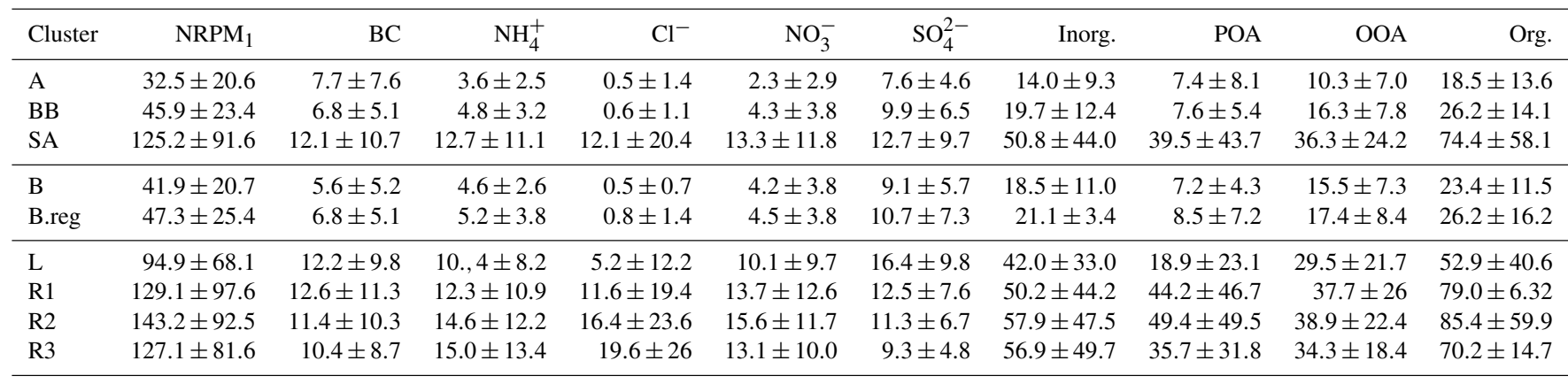

by the ICARB campaign (Kalapureddy et al., 2009). Previous studies (Nair et al., 2008a, b; Moorthy et al., 2008) reported higher aerosol number concentration $\left(N_{\mathrm{CN}}\right)$, as well as black carbon (BC) concentration, over the Bay of Bengal than over the Arabian Sea, in all size ranges within the marine boundary layer as well as the vertical column. The BB air mass travelled over the Indo-Gangetic Plain (IGP), and the AS air mass travelled across western India and the desert region of Rajasthan. Based on previous emission estimates (Habib et al., 2006), the emission fluxes from fossil fuel dominate the aerosol burden over the IGP. The aerosol over the IGP is largely composed of inorganic oxidized matter (IOM), including fly ash from coal-fired power plants and mineral matter from open crop waste burning (Habib et al., 2006). The AS air mass travels over western India and brings pollution from both fossil fuel combustion and desert dust (Habib et al., 2006).

\section{2 $\mathrm{PM}_{1}$ chemical composition of different air masses}

Mass closure between SMPS size distribution data and the sum of ACSM species together with BC was achieved $\left(R^{2}=\right.$ 

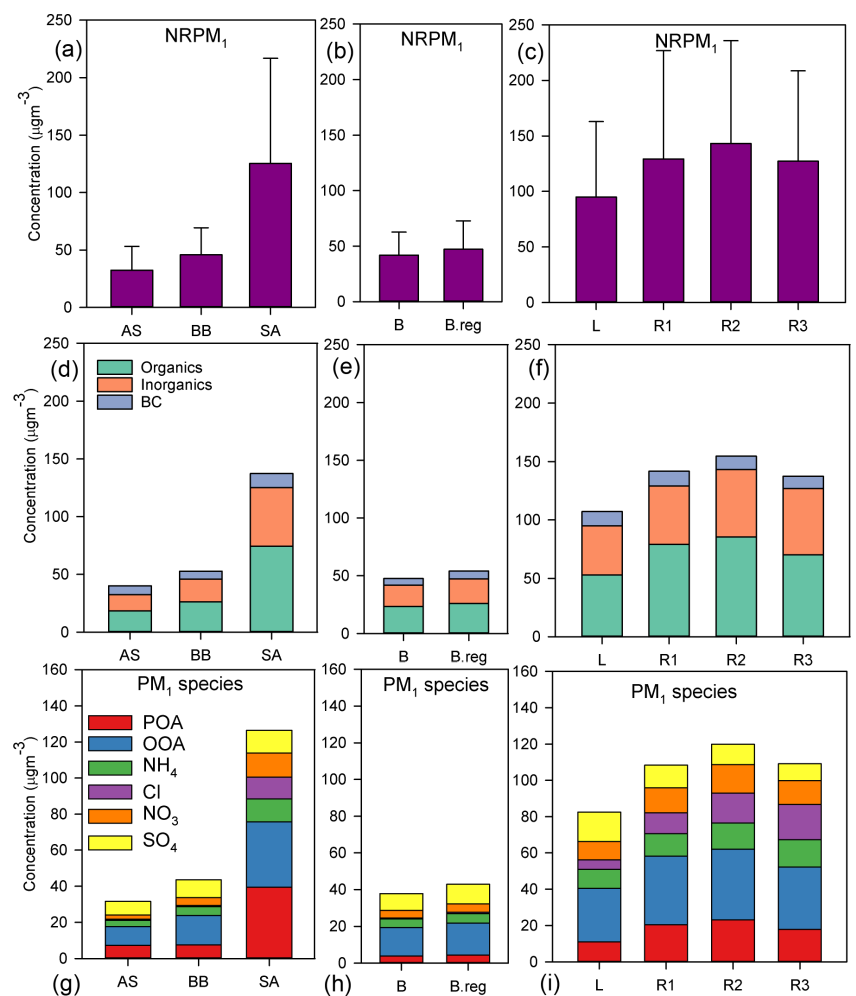

Figure 2. Mean values of (a-c) $\mathrm{NRPM}_{1}$; (d-f) organics, inorganics, and $\mathrm{BC}$; and (g-i) $\mathrm{PM}_{1}$ species (from top to bottom) for the various air masses. Panels (a), (d), and (g) are for AS, BB, and SA; (b), (e), and (h) are for BB branches (B and B.reg); and (c), (f), and (i) are for SA branches (L, R1, R2, and R3).

Table 2. Cluster means of $f_{57}$ and $f_{60}$ values for all branches, where SD means standard deviation.

\begin{tabular}{lrr|rr}
\hline \multirow{2}{*}{ Cluster } & \multicolumn{2}{c|}{$f_{57}$} & \multicolumn{2}{c}{$f_{60}$} \\
\cline { 2 - 5 } & Mean & SD & Mean & SD \\
\hline A & 0.02389 & 0.00777 & 0.004061 & 0.001199 \\
BB & 0.0205 & 0.006107 & 0.004294 & 0.000962 \\
SA & 0.02499 & 0.007663 & 0.007089 & 0.003569 \\
\hline B & 0.02088 & 0.005959 & 0.004368 & 0.000916 \\
B.reg & 0.01998 & 0.006266 & 0.004192 & 0.001012 \\
\hline L & 0.0239 & 0.007179 & 0.006023 & 0.002404 \\
R1 & 0.0254 & 0.007878 & 0.00717 & 0.003861 \\
R2 & 0.02509 & 0.00764 & 0.007851 & 0.003576 \\
R3 & 0.02427 & 0.006971 & 0.007084 & 0.002992 \\
\hline
\end{tabular}

0.83 ) as detailed in our parallel paper (Gani et al., 2019). The $\mathrm{NRPM}_{1}$ species $\left(\mathrm{NH}_{4}^{+}, \mathrm{Cl}^{-}, \mathrm{NO}_{3}^{-}, \mathrm{SO}_{4}^{2-}, \mathrm{POA}\right.$, and OOA) and $\mathrm{BC}$ varied significantly for the different air masses, both in terms of the mass of species (Fig. 2c) and the diurnal patterns (Fig. 3), leading to different aerosol chemistry and chemical reactions. A summary of the average mass of each species for all air masses is detailed in Table 1 . In brief, both
POA and OOA, followed by $\mathrm{NO}_{3}^{-}, \mathrm{SO}_{4}^{2-}$, and $\mathrm{Cl}^{-}$, dominated the PM composition for the SA air mass, while OOA, followed by $\mathrm{SO}_{4}^{2-}$ and OOA, was dominant for $\mathrm{BB}$ and $\mathrm{AS}$ air masses. High chloride was a special feature of the SA air mass which was not apparent in the other two branches.

$\mathrm{NH}_{4}^{+}$was assumed to be the dominant cation based on high aerosol neutralization ratio (ANR) values (mean values ranging from 0.95 to 0.85 ). The ANR is defined as the normalized ratio of the measured $\mathrm{NH}_{4}^{+}$concentration to the $\mathrm{NH}_{4}^{+}$concentration needed for full neutralization of the anions and calculated as per Eq. (5) (Zhang et al., 2007):

$$
\begin{aligned}
\mathrm{ANR} & =\frac{\mathrm{NH}_{4}^{+} \text {meas }}{\mathrm{NH}_{4}^{+} \text {neut }} \\
& =\frac{\left(\mathrm{NH}_{4}^{+} / 18\right)}{\left(2 \times \mathrm{SO}_{4}^{2-} / 96\right)+\left(\mathrm{NO}_{3}^{-} / 62\right)+\left(\mathrm{Cl}^{-} / 35.5\right)}
\end{aligned}
$$

Detailed ANR values are given in Table S1 in the Supplement. ANR values revealed that while AS, B, and L branches were completely neutralized, B.reg, R1, R2, and R3 were only partly neutralized, indicating that minor components of sulfate, chloride, and nitrate may be bound to non-volatile salts such as $\mathrm{NaNO}_{3}, \mathrm{NaCl}$, or $\mathrm{Na}_{2} \mathrm{SO}_{4}$ or are associated with organics as organosulfates, organochlorides, or organonitrates, evidence for which is shown in a previous DAS study (Bhandari et al., 2020).

To determine the dominant salts, $\mathrm{NH}_{4}^{+}$ions were neutralized with $\mathrm{SO}_{4}^{2-}$ ions. The speciation of salts of $\mathrm{NH}_{4}^{+}$and $\mathrm{SO}_{4}^{2-}$ was determined by the molar ratio of $\mathrm{NH}_{4}^{+}$to $\mathrm{SO}_{4}^{2-}$ ions $\left(R\left[\mathrm{SO}_{4}^{2-}\right]\right) . R\left[\mathrm{SO}_{4}^{2-}\right]>2$ is indicative of $\left(\mathrm{NH}_{4}\right)_{2} \mathrm{SO}_{4}$, while $1<R\left[\mathrm{SO}_{4}^{2-}\right]<2$ indicates a mixture of $\left(\mathrm{NH}_{4}\right)_{2} \mathrm{SO}_{4}$ and $\mathrm{NH}_{4} \mathrm{HSO}_{4}$, and $R\left[\mathrm{SO}_{4}^{2-}\right]<1$ indicates a mixture of $\mathrm{H}_{2} \mathrm{SO}_{4}$ and $\mathrm{NH}_{4} \mathrm{HSO}_{4}$ (Nenes et al., 1998; Asa-Awuku et al., 2011; Padró et al., 2012). For Delhi, $R\left[\mathrm{SO}_{4}^{2-}\right]>2$ was obtained for all branches, indicating that $\left(\mathrm{NH}_{4}\right)_{2} \mathrm{SO}_{4}$ was present in all branches. Furthermore, the non-sulfate $\mathrm{NH}_{4}^{+}$ ions $\left[\mathrm{ns}-\mathrm{NH}_{4}^{+}\right]$were calculated, as per $\left[\mathrm{ns}-\mathrm{NH}_{4}^{+}\right]=\left[\mathrm{NH}_{4}^{+}\right]-$ $2 \times\left[\mathrm{SO}_{4}^{2-}\right]$. The $r^{2}$ values were then determined for the coupling of ns- $\mathrm{NH}_{4}^{+}$ions with (a) $\mathrm{Cl}^{-}$ions, (b) $\mathrm{NO}_{3}^{-}$ions, and (c) $\left[\mathrm{NO}_{3}^{-}+\mathrm{Cl}^{-}\right]$ions jointly (Du et al., 2010). All $r^{2}$ values are detailed in Table S1. This analysis revealed that $\left(\mathrm{NH}_{4}\right)_{2} \mathrm{SO}_{4}$ is the dominant salt for AS and B branches based on $r_{\mathrm{NH}_{4}^{+} / \mathrm{SO}_{4}^{2-}}^{2-}$ values of 0.78 for AS and 0.75 for $\mathrm{BB} 0.75$. $\mathrm{NH}_{4} \mathrm{Cl}$ formation for SA was confirmed by a high $r^{2}$ value (0.90) for $\mathrm{ns}_{-} \mathrm{NH}_{4}^{+}$coupling with $\mathrm{Cl}^{-}$. A similar finding is reported by Bhandari et al. (2020) based on the coupling of the $\mathrm{NH}_{4} \mathrm{Cl}$ factor with wind direction. Coupling of $n s-\mathrm{NH}_{4}^{+}$ with $\mathrm{NO}_{3}^{-}$revealed a good correlation for $\mathrm{B}(0.70)$ and B.reg (0.63) (Fig. S6). In all cases, an increase in $r^{2}$ for combined $\mathrm{NO}_{3}^{-}+\mathrm{Cl}^{-}$as compared to individual ions indicates that both $\mathrm{HNO}_{3}$ and $\mathrm{HCl}$ were synchronously neutralized by $\mathrm{NH}_{3}$. If $\mathrm{Cl}^{-}$and $\mathrm{NO}_{3}^{-}$are present in the fine mode, they are expected to be in the form of their respective ammonium salts 

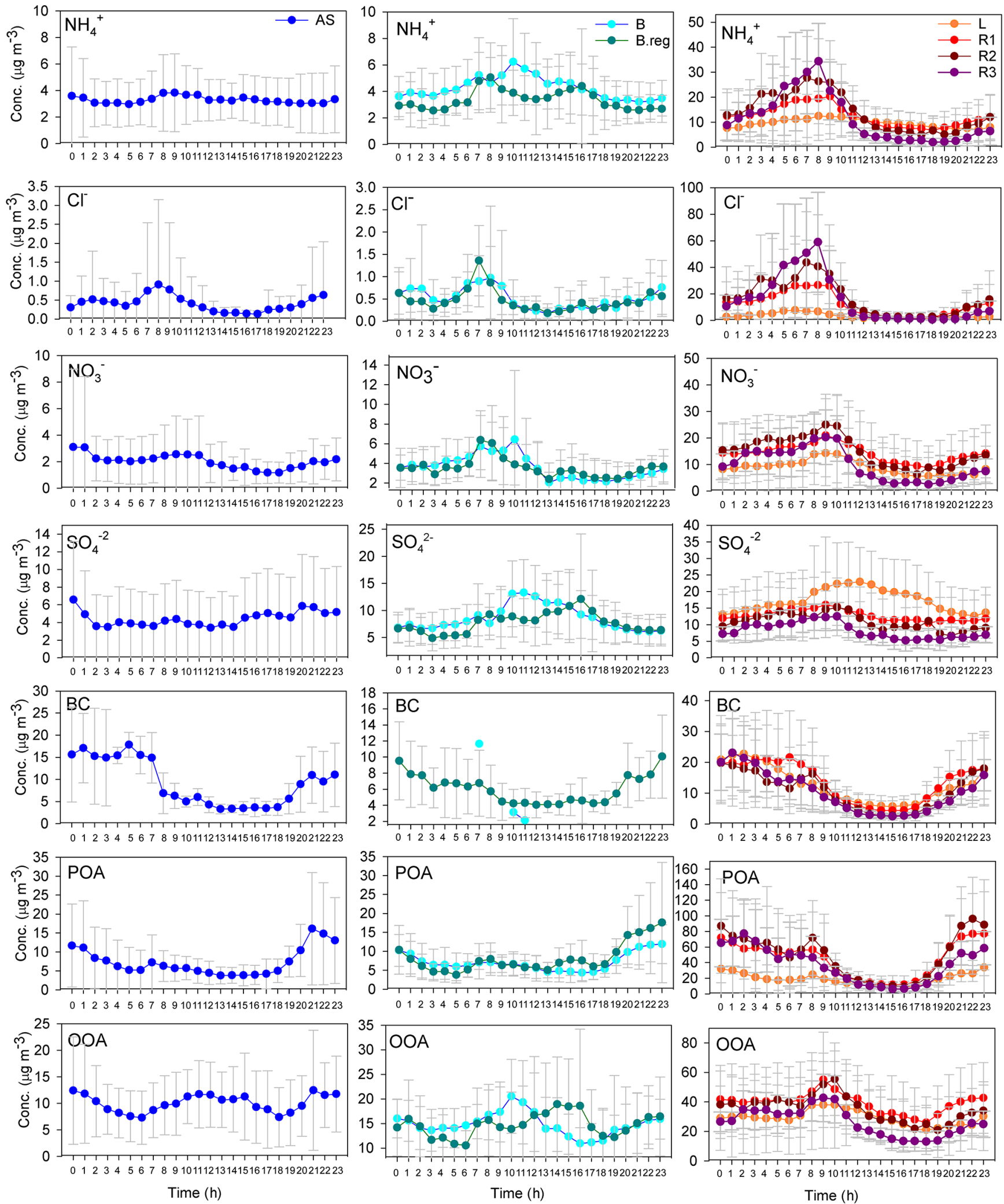

Figure 3. Diurnal variation in $\mathrm{NRPM}_{1}$ species $\left(\mathrm{NH}_{4}^{+}, \mathrm{Cl}^{-}, \mathrm{NO}_{3}^{-}, \mathrm{SO}_{4}^{2-}\right.$, $\mathrm{POA}$, and OOA) and $\mathrm{BC}$ for $\mathrm{AS}$ on the left, $\mathrm{BB}(\mathrm{B}$ and $\mathrm{B} . r e g)$ in the middle, and SA (L, R1, R2, and R3) air masses on the right. 
(Harrison and Pio, 1983). Thus, the dominating salts were $\left(\mathrm{NH}_{4}\right)_{2} \mathrm{SO}_{4}$ for $\mathrm{AS},\left(\mathrm{NH}_{4}\right)_{2} \mathrm{SO}_{4}$ and $\mathrm{NH}_{4} \mathrm{NO}_{3}$ for the $\mathrm{BB}$ air mass, and $\mathrm{NH}_{4} \mathrm{Cl}$ for $\mathrm{SA}$ and its sub-branches.

The organic speciation revealed that AS organics were BBOA; BB (both B and B.reg) organics were a mix of the three; and SA organics were BBOA, wherein L, R1, and R2 organics were $\mathrm{BBOA}$ while $\mathrm{R} 3$ organics were both $\mathrm{HOA}$ and BBOA.

The $\mathrm{NO}_{x}$ emissions (in $\mu \mathrm{g} \mathrm{m}^{-3}$ ) for the $\mathrm{SA}$ air mass $(96.88 \pm 127.22)$ were the highest, followed by those in BB $(38.30 \pm 64.79)$ and then those in the AS $(36.71 \pm 68.13)$ air mass. $\mathrm{BB}$ is representative of B.reg only, as $\mathrm{NO}_{x}$ data for the $\mathrm{B}$ air mass were not available. $\mathrm{NO}_{x}$ data for AS were also scarce. The $\mathrm{SA}$ aerosols exhibited less ageing $(4.38 \pm 4.49 \mathrm{~h})$ compared to B.reg. (11.58 $\pm 3.45 \mathrm{~h}$ ), but both were representative of aged aerosols. Ageing was not calculated for AS due to very little data availability.

To determine the presence of biomass burning and traffic emissions, BCwb (wood-burning component) and BCff (traffic component) for all air masses were determined, based on aethalometer data, as per Sandradewi et al. (2008). The contributions of $\mathrm{BCwb}$ and $\mathrm{BCff}$ are summarized in Table S4. Since fossil fuel sources are active year-round, there was a strong presence of $\mathrm{BCff}$, ranging from $70 \%$ to $86 \%$. However, biomass burning is only active during certain specific times for short durations and is very prominent in the northwestern direction for the SA air masses. It was observed that the more distant air masses exhibited a higher $\mathrm{BCwb}$ contribution compared to those originating within proximity. Hence, while L was associated with $13.9 \% \mathrm{BCwb}, \mathrm{R} 3$ exhibited $29.2 \% \mathrm{BCwb}$. The $\mathrm{BCwb}$ contribution for $\mathrm{A}$ and BB air masses was $21 \%$. It can thus be concluded that both biomass burning and traffic emissions are important sources contributing to the chemical composition of the various air masses.

\subsection{Diurnal variation in chemical species and probable sources}

\subsubsection{The southern Asian air mass}

This air mass ranked highest in $\mathrm{NH}_{4}^{+}$concentration compared to other branches. Locally (i.e. for L), the source for $\mathrm{NH}_{4}^{+}$may be attributed to $\mathrm{NH}_{3}$ gas from the nearby agricultural fields of the Indian Agricultural Research Institute (IARI) (Sharma et al., 2014). For R1, R2, and R3, sharp spikes in early morning hours seen in the diurnal patterns of $\mathrm{NH}_{4}^{+}$indicate its formation from ammonia as a result of industrial exhaust of untreated ammonia. This is because its diurnal variation is very similar to the diurnal of $\mathrm{NH}_{3}$ emissions of an industrial origin (Wang et al., 2015). A very prominent feature of the SA that made it distinct from the other two air masses was the presence of high chloride $\left(\left[\mathrm{Cl}^{-}\right]_{\mathrm{L}}<\left[\mathrm{Cl}^{-}\right]_{\mathrm{R} 1}<\left[\mathrm{Cl}^{-}\right]_{\mathrm{R} 2}\right.$ and $\left.\left[\mathrm{Cl}^{-}\right]_{\mathrm{R} 3}\right)$. High $\mathrm{Cl}^{-}$in the SA branch can be attributed to several factors: (a) Khewra salt mines in Pakistan that might contribute to high $\mathrm{Cl}^{-}$ in other branches compared to L; (b) locally, plastic burning, refuse burning, and soil dispersion; (c) biomass burning, which is a very prominent feature of the SA branch, as indicated by $f_{57}$ and $f_{60}$ values and also by a large number of fire counts from MODIS fire-count data (Bhattu and Tripathi, 2015), dominantly in Punjab, Haryana, and a few places in Pakistan; (e) coal-based thermal power plants in Delhi, Punjab, Haryana, and Pakistan; and (f) small- and medium-scale metal processing industries in Delhi, Punjab, and Haryana, where $\mathrm{HCl}$ is used in a pickling process of hot and cold rolling of steel sheets and acid recovery from fume generation is not practised (Jaiprakash et al., 2017).

As far as the increase in chloride with the increasing length of trajectories is concerned, the most plausible explanation is biomass burning. It is pointed out in Sect. 3.2 that $\mathrm{BCwb}$ contribution increases as the air mass trajectories become distant, a feature similar to chloride emissions. There was a marked similarity in the diurnal patterns of $\mathrm{NH}_{4}^{+}$and $\mathrm{Cl}^{-}$ ions such that the sequence of $\left[\mathrm{Cl}^{-}\right]$for SA sub-branches was also valid for $\left[\mathrm{NH}_{4}^{+}\right]$, indicating the formation of $\mathrm{NH}_{4} \mathrm{Cl}$. $\mathrm{NH}_{4} \mathrm{Cl}$ may also be emitted directly from cement plants (Cheney et al., 1983) in Punjab. The equilibrium constant for $\mathrm{Cl}^{-}$ is more sensitive to ambient temperature than $\mathrm{NO}_{3}^{-}$, as a result of which, during the daytime, a large amount of $\mathrm{NH}_{4} \mathrm{Cl}$ dissociates to form $\mathrm{NH}_{3}$ and $\mathrm{HCl}$ if the temperature exceeds $10^{\circ} \mathrm{C}$ (Kaneyasu et al., 1999). The diurnal patterns of both $\left[\mathrm{NH}_{4}^{+}\right]$and $\left[\mathrm{Cl}^{-}\right]$exhibited a sharp decrease after 08:00 LT (all times listed in the paper are in local time, UTC+5:30) in the morning, which is obvious, since $\mathrm{NH}_{4}^{+}$for the $\mathrm{SA}$ air mass is mostly associated with $\mathrm{Cl}^{-}$. At the same time $\left[\mathrm{NO}_{3}^{-}\right]$showed an increase between 09:00 and 10:00 and then started decreasing, but the rate of decrease was lower than $\mathrm{NH}_{4} \mathrm{Cl}$. This is expected, as $\mathrm{NH}_{4} \mathrm{NO}_{3}$ is more stable than $\mathrm{NH}_{4} \mathrm{Cl}$ (Kaneyasu et al., 1999). During winter, the ambient temperature drops slightly below $10^{\circ} \mathrm{C}$ in the morning hours, increases sharply after 08:00 to reach a maximum at 14:00, and then again starts decreasing and reaches around $10^{\circ} \mathrm{C}$ at midnight (Gani et al., 2019). Since during winters, the air mass comes mostly from the north-western direction of the SA air mass, it is evident that the formation and dissociation of $\mathrm{NH}_{4} \mathrm{Cl}$ were governed by the ambient temperature at the receptor site.

The reduction in chloride concentrations at midday can also be attributed to sulfate substitution mechanism, when sulfate formation enhances, and was also marked by the ratio $R\left[\mathrm{SO}_{4}^{2-}\right]$ ratio greater than 2 for $\mathrm{L}, \mathrm{R} 1, \mathrm{R} 2$, and $\mathrm{R} 3$. This is valid especially for $\mathrm{L}$, wherein $\left[\mathrm{SO}_{4}^{2-}\right]$ increased significantly. However, the diurnal patterns of $\left[\mathrm{SO}_{4}^{2-}\right]$ and $\left[\mathrm{NH}_{4}^{+}\right]$ did not resemble each other, indicating that $\left(\mathrm{NH}_{4}\right)_{2} \mathrm{SO}_{4}$ may be present in small amounts, but primarily $\mathrm{SO}_{4}^{2-}$ is associated elsewhere. Hence, $\mathrm{SO}_{4}^{2-}$ in combined form can be expressed in two ways: (a) small amounts of $\left(\mathrm{NH}_{4}\right)_{2} \mathrm{SO}_{4}$ and (b) mostly in combination with $\mathrm{K}^{+}$. Thus, the sharp jump in $\left[\mathrm{SO}_{4}^{2-}\right]$ in 
locally originated air masses in the late morning and afternoon hours may be attributed to $\mathrm{SO}_{2}$ emissions. $\mathrm{SO}_{2}$ emissions in India are primarily attributed to power generation plants that make use of coal combustion as the chief source (Reddy and Venkataraman, 2002), followed by transportation. Such coal-based power plants are located in the IGP, with a high concentration in Haryana. $\mathrm{SO}_{2}$ dissolves readily in water and can form sulfite ion, which in the presence of ozone can form sulfate ion (Erickson et al., 1977). $\mathrm{H}_{2} \mathrm{SO}_{4}$ formed from the reaction of $\mathrm{SO}_{2}$ and ozone can react with $\mathrm{NH}_{3}$ to form $\mathrm{NH}_{4} \mathrm{HSO}_{4}$, which combines with $\mathrm{NH}_{3}$ again to form $\left(\mathrm{NH}_{4}\right)_{2} \mathrm{SO}_{4}$ (Stelson and Seinfeld, 1982; Seinfeld, 1986). Since the ozone spiked during the daytime (10:0016:00), more sulfate formation was seen when ozone was maximum. The diurnal variation for ozone is explained in Gaur et al. (2014) for Kanpur, where a spike in ozone levels was seen during 10:00-16:00. A peak in sulfate concentration was also previously observed for the foggy period in Kanpur at 10:00 due to the resumption of photochemical activity after fog dissipation (Chakraborty et al., 2015). $\mathrm{SO}_{4}^{2-}$ in $\mathrm{SA}$ branches may also combine with $\mathrm{K}^{+}$, as $\mathrm{K}^{+}$is produced in biomass burning. Evidence for the presence of $\mathrm{K}^{+}$ along with $\mathrm{SO}_{4}^{2-}$ in the accumulation mode is reported in Fuzzi et al. (2007). $\mathrm{SO}_{4}^{2-}$ and $\mathrm{NO}_{3}^{-}$emissions may also be associated with secondary formation for R1, R2, and R3 due to industrial emissions from metal product manufacturing industries in Punjab and Haryana; large-scale manufacturing of porcelain insulators; switchgear in Islamabad (Jaiprakash et al., 2017); and steel rolling mills in Iran, Iraq, and Turkey and Punjab.

The $\mathrm{NO}_{3}^{-}$levels were very high for SA. The high $\mathrm{NO}_{3}^{-}$in SA can be explained by the non-ideal burning of $\mathrm{NH}_{4} \mathrm{NO}_{3}$ and $\mathrm{NO}_{x}$ emissions due to mining equipment in the coal mines in Pakistan, leading to high $\mathrm{NO}_{3}^{-}$formation (Chakraborty et al., 2015). It is mentioned in Sect. 3.2 that $\mathrm{NO}_{x}$ emissions in the SA branch are very high. $\mathrm{NH}_{4}^{+}$neutralizes $\mathrm{NO}_{3}^{-}$simultaneously with $\mathrm{Cl}^{-}$; however, the correlation of $\left[\mathrm{NO}_{3}^{-}\right]$with $\left[\mathrm{ns}-\mathrm{NH}_{4}^{+}\right]$is moderate for $\mathrm{SA}$. Therefore, it is expected that $\mathrm{NO}_{3}^{-}$might be associated with $\mathrm{K}^{+}$and $\mathrm{Na}^{+}$, since biomass burning results in $\mathrm{K}^{+}$and $\mathrm{Na}^{+}$emissions (Fuzzi et al., 2007). $\mathrm{K}^{+}$and $\mathrm{Na}^{+}$exhibit a high affinity for nitrate during neutralization reactions, thus aiding in particulate nitrate formation (Bi et al., 2011). This is in addition to other nitrate sources that are discussed above along with $\mathrm{SO}_{4}^{2-}$ sources for $\mathrm{SA}$.

The BC concentrations were highest for SA, followed by those in AS and then those in BB. The biomass burning in the SA air mass could be a major source of BC besides power plants, cement plants, local traffic, and industries. The POA emissions for SA followed the order $\mathrm{BC}_{(\mathrm{L})}<\mathrm{BC}_{(\mathrm{R} 3)}<$ $\mathrm{BC}_{(\mathrm{R} 1)}<\mathrm{BC}_{(\mathrm{R} 2)}$. The spikes during the early morning hours and nighttime of the POA diurnal profile may be attributed to lower boundary layer heights during the two periods. BC and POA were well correlated $\left(r^{2}=0.77\right)$ for R3, indicating that they come from primary emissions. The diurnal profiles for all branches were similar, which shows a decline as the day proceeds, followed by an increase as the night proceeds. OOA was present significantly in all the three branches but is maximum for SA. Its diurnal variation resembled that of $\mathrm{NO}_{3}^{-}\left(r^{2}=0.78\right)$, indicative of its semi-volatile nature. OOA and $\mathrm{NO}_{3}^{-}$correlations were strongest for $\mathrm{L}\left(r^{2}=0.91\right)$, followed by R2 $\left(r^{2}=0.85\right), \mathrm{R} 3\left(r^{2}=0.81\right)$ and R1 $\left(r^{2}=0.75\right)$.

\subsubsection{The Bay of Bengal air mass}

$\left[\mathrm{Cl}^{-}\right]$was lower in this air mass compared to that in SA. For both of the BB branches, fossil fuel combustion was the most likely source of $\mathrm{Cl}^{-}$, as fossil fuel emissions dominate the IGP. $\mathrm{Cl}^{-}$for BB was not correlated with $\mathrm{ns}-\mathrm{NH}_{4}^{+}$and may be present in the form of methyl chloride, methylene chloride, carbon tetrachloride, and tetrachloroethene (Ho et al., 2004).

Fossil fuel combustion from coal plants along the IGP can be explained as a common source for both $\mathrm{SO}_{4}^{2-}$ and $\mathrm{NH}_{4}^{+}$ ions, leading to $\left(\mathrm{NH}_{4}\right)_{2} \mathrm{SO}_{4}$ formation $\left(r_{\mathrm{NH}_{4}^{+} / \mathrm{SO}_{4}^{2-}}^{2}=0.78\right)$. This was also seen in the diurnal profiles of $\left[\mathrm{SO}_{4}^{2-}\right]$ and $\left[\mathrm{NH}_{4}^{+}\right]$, both of which exhibited a sharp spike in the early morning hours between 10:00 and 16:00. $\mathrm{SO}_{2}$ emissions, as explained for $\mathrm{SA}$ via photochemical oxidation by $\mathrm{O}_{3}$ in combination with $\mathrm{NH}_{3}$, can lead to $\left(\mathrm{NH}_{4}\right)_{2} \mathrm{SO}_{4}$ formation. For the B.reg branch, the diurnal profiles of $\mathrm{NH}_{4}^{+}$and $\mathrm{SO}_{4}^{2-}$ exhibited double spikes ( $\mathrm{M}$ pattern, which is a typical feature of $\mathrm{NO}_{x}$ profile for traffic emissions) during heavy traffic hours (06:00-08:00 and around 16:00-19:00), indicating $\left(\mathrm{NH}_{4}\right)_{2} \mathrm{SO}_{4}$ formation. $\mathrm{NO}$ from automobile exhaust can also form $\mathrm{NH}_{3}$ in three ways catalytic convertors (Gandhi and Shelf, 1991), which in combination with $\mathrm{SO}_{2}$, formed due to pyrolysis of sulfide fuels and subsequent oxidation, can lead to $\left(\mathrm{NH}_{4}\right)_{2} \mathrm{SO}_{4}$ formation.

The correlation of $\left[\mathrm{NO}_{3}^{-}\right]$with $\left[\mathrm{ns}^{-} \mathrm{NH}_{4}^{+}\right]$was appreciably high for both $\mathrm{B}$ and B.reg. For both these branches, the fossil fuel combustion resulting in $\mathrm{NO}_{3}^{-}$emissions in combination with $\mathrm{NH}_{4}^{+}$(Rajput et al., 2015; Pan et al., 2016) can lead to $\mathrm{NH}_{4} \mathrm{NO}_{3}$ formation. This is also evident from the diurnal profile of $\mathrm{NO}_{3}^{-}$that shows a very similar pattern to $\mathrm{NH}_{4}^{+}$and is expected to be in the form of $\mathrm{NH}_{4} \mathrm{NO}_{3}$. The diurnal profiles of $\mathrm{NO}_{3}^{-}$show a decline as the temperature increases during the day and $\mathrm{NO}_{3}^{-}$converts back to $\mathrm{HNO}_{3}$ due to its semivolatile nature.

The BC concentration in BB air masses was considerably lower than in the SA air masses. The missing points in the diurnal variability in $\mathrm{BC}$ for the $\mathrm{B}$ region are on account of the unavailability of aethalometer data. The BC in the IGP can be emitted from industries (as for B), traffic (as for B.reg), and natural sources (Derwent et al., 2001). For B and B.reg, the B.reg branch was subjected to a longer duration of anthropogenic influence compared to $\mathrm{B}$, which also spent considerable time on the water; hence after the early morning hours, 
when the various fresh emissions start increasing, the magnitude of POA for B.reg exceeds B. However, POA for BB was very low compared to SA. For B.reg, the spike in OOA during daytime hours was very similar to that of odd oxygen $\left(\mathrm{O}_{3}+\mathrm{NO}_{2}\right)$ for Delhi. The $\mathrm{O}_{x}$ profile for Delhi is given in Tiwari et al. (2015), indicating its production by local photochemistry despite the increase in boundary layer height in the afternoon. The similarity in OOA and $\mathrm{O}_{x}$ diurnal profiles was also noted for Kanpur (Chakraborty et al., 2016).

\subsubsection{The Arabian Sea air mass}

Chloride amounts were very low for AS compared to that in SA. Biomass burning as indicated by $f_{57}$ and $f_{60}$ measurements seems to be the main $\mathrm{Cl}^{-}$contributor to AS and might be associated with $\mathrm{K}^{+}$, which is also emitted along with it.

Similar to the cases of the $\mathrm{L}$ branch in the case of the SA air mass and the BB air mass, the power stations in Gujarat and Rajasthan lead to $\mathrm{SO}_{2}$ emissions. Since the power plants in this region, over which the AS air mass traverses, are relatively small in number, the $\mathrm{SO}_{2}$ concentration is much lower compared to that in the $\mathrm{BB}$ air masses. $\mathrm{SO}_{2}$ emissions subsequently lead to $\left(\mathrm{NH}_{4}\right)_{2} \mathrm{SO}_{4}$ formation, which was the main salt present in this branch and was also evident from the high correlation between the two ions. $\left(\mathrm{NH}_{4}\right)_{2} \mathrm{SO}_{4}$ may be formed due to emissions from both power plants and traffic (similar to B.reg). Traffic emissions can be understood from the $\mathrm{M}$ pattern in diurnal profiles of $\mathrm{NH}_{4}^{+}$and $\mathrm{SO}_{4}^{2-}$, though the variation was not very pronounced and might be suppressed due to power plant emissions. The traffic signal was more clearly implied by the diurnal profile of $\left(\mathrm{NH}_{4}\right)_{2} \mathrm{SO}_{4}$ for AS, as seen in Fig. S2. The correlation of $\left[\mathrm{NO}_{3}^{-}\right]$with $\left[\mathrm{ns}^{-} \mathrm{NH}_{4}^{+}\right]$was very poor for AS, indicating that $\mathrm{NO}_{3}^{-}$might be associated with $\mathrm{K}^{+}$and $\mathrm{Na}^{+}$, similar to B.reg.

Both $\mathrm{BC}$ and POA for the AS air mass were less than in the SA air mass. However, compared to BB, BC was slightly higher and POA was comparable. BC was likely of an industrial origin. The POA diurnal profile was similar to the other air masses. Similar to B.reg, the OOA diurnal pattern resembled that of odd oxygen, where the odd-oxygen profile is reported in Tiwari et al. (2015).

Thus, the direct emission sources and the precursors $\left(\mathrm{SO}_{x}\right.$, $\mathrm{NO}_{x}, \mathrm{NH}_{3}, \mathrm{O}_{3}$, and $\mathrm{O}_{x}$ ) that lead to particulate matter formation strongly impacted the chemical properties of aerosols. The chemical properties of aerosol also impacted the hygroscopicity of aerosols, as is discussed in the following section.

\subsection{Impact of chemical composition on the hygroscopicity of air masses}

This study provides the first long-term estimation of aerosol hygroscopicity in the $\mathrm{PM}_{1}$ regime. The mean $\kappa$ was approximately the same for all the air masses, which is $\sim 0.3$ $(0.32 \pm 0.06$ for AS, $0.31 \pm 0.06$ for BB, and $0.32 \pm 0.10$ for $\mathrm{SA}$ ) and in line with the global average value of $0.27 \pm 0.21$ for continental aerosols (Andreae and Rosenfeld, 2008; Petters and Kreidenweis, 2007; Pöschl et al., 2009; Pringle et al., 2010). Including BC in $\kappa$ calculations leads to a difference of $10 \%$ in $\kappa$ on average, shifting the mean $\kappa$ of 0.32 to 0.29 . The BC mass fraction and volume fractions were $10 \%$ and $9 \%$, respectively. Thus, the change in $\kappa$ due to the introduction of $\mathrm{BC}$ was not significant.

$\kappa$ varied from 0.13 to 0.77 , and there was a difference in the diurnal variation in the hygroscopicity parameter for the various air masses (Fig. 4). A similar finding was observed in China, with a mean $\kappa$ of 0.3 , varying in the range 0.10.5 (Rose et al., 2010). Recently, $\kappa$ of $0.42 \pm 0.07$ was also reported for $\mathrm{PM}_{2.5}$ for Delhi based on beta attenuation monitor (BAM) measurements of $\mathrm{PM}_{2.5}$ (Wang and Chen, 2019), using an indirect method in the absence of direct measurements. Thus, the dependence of $\kappa$ on size cannot be underestimated for Delhi and should be dealt with in the future.

Variation in $\kappa$ with size has been seen in several places in the world; e.g. at $97 \% \mathrm{RH}$, mass growth factors of 6.95 and 9.78 were reported for the size ranges $0.53-1.6$ and 1.6-5.1 $\mu \mathrm{m}$, respectively, on the Slovenian coast (Turšič et al., 2006). Aitken mode $\kappa$ was 0.25 , while the accumulation mode $\kappa$ was 0.45 for Beijing (Gunthe et al., 2011). An increase in $\kappa$ for the higher size regime points to the fact that the organic fraction is higher in the smaller size range, while the inorganic fraction increases substantially with size.

In the $\mathrm{PM}_{1}$ size range, while $\kappa$ of 0.1 indicates secondary organic aerosol, $\kappa$ varied from 0.01 to 0.8 for biomassburning aerosols in lab studies (Petters et al., 2009). $\kappa$ varied from 0.15 to 0.25 , with lower values (around 0.16 ) being observed during the night, when biomass-burning particles prevailed during wintertime in Athens, Greece (Psichoudaki et al., 2018). Thus, $\kappa$ values for Delhi can represent both secondary formation and biomass burning. This is true for Delhi, which had both POA and OOA in all the air masses, while BBOA was present in AS and SA air masses, as detailed in the preceding sections on chemical properties.

An important observation for all branches is that when the inorganic volume fraction (of dominant salt) increased (Fig. S2), during the times when $\kappa$ was high (Fig. 4), or when the organic volume fraction decreased (Fig. S2), a dip in $D_{\mathrm{c}}$ (Fig. 6) was seen, implying that a larger size regime was available for activation. The diurnal variation in $\kappa$ (Fig. 4) more strongly followed the diurnal pattern of the dominant inorganic salts for a cluster (Fig. S2), since the hygroscopicity parameters for inorganic salts are considerably higher than those of organics. Pearson correlation coefficient $(r)$ values between $\kappa$ and the salt volume fractions revealed that the diurnal patterns of $\kappa$ were governed dominantly by volume fractions of $\left(\mathrm{NH}_{4}\right)_{2} \mathrm{SO}_{4}(r: 0.85)$ for AS, moderately by $\left(\mathrm{NH}_{4}\right)_{2} \mathrm{SO}_{4}(r: 0.55)$ and $\mathrm{NH}_{4} \mathrm{NO}_{3}(r: 0.49)$ for $\mathrm{BB}$, and dominantly by $\mathrm{NH}_{4} \mathrm{Cl}$ for $\mathrm{SA}$ air masses. For the two $\mathrm{BB}$ branches, $\kappa$ of the $\mathrm{B}$ branch was governed dominantly by $\left(\mathrm{NH}_{4}\right)_{2} \mathrm{SO}_{4}(r: 0.78)$ and moderately by $\left(\mathrm{NH}_{4}\right)_{2} \mathrm{SO}_{4}(r$ : $0.57)$ and $\mathrm{NH}_{4} \mathrm{NO}_{3}(r: 0.54)$ for B.reg. For $\mathrm{SA}$ air masses, 

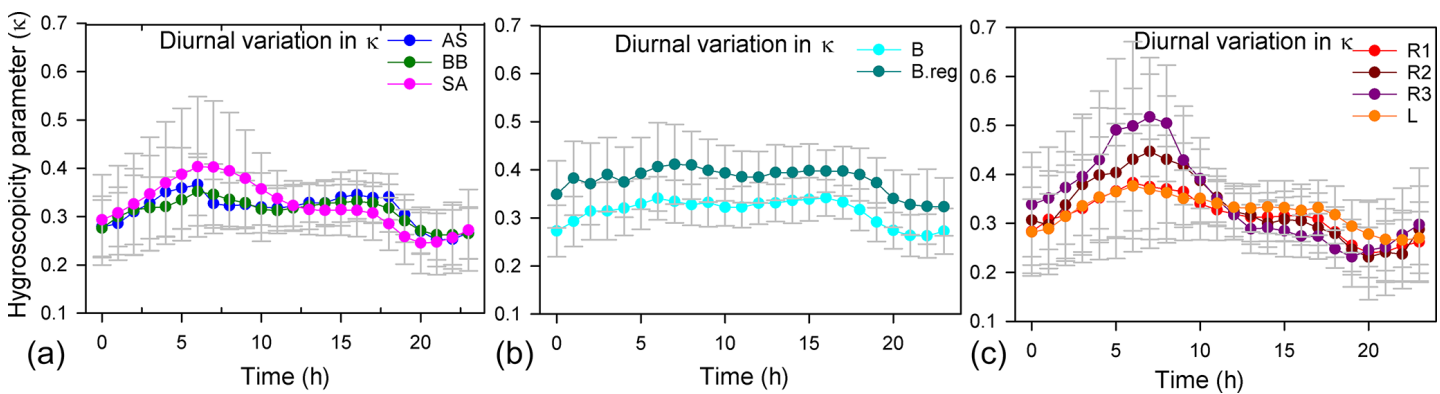

Figure 4. Diurnal variation in $\kappa$ with time. Panel (a) is for AS, BB, and SA; panel (b) is for BB branches (B and B.reg), and panel (c) is for SA branches (L, R1, R2, and R3).

$\kappa$ of $\mathrm{R} 1, \mathrm{R} 2$, and $\mathrm{R} 3$ was governed dominantly by $\mathrm{NH}_{4} \mathrm{Cl}(r$ values of $0.71,0.89$, and 0.95$)$ and jointly by $\mathrm{NH}_{4} \mathrm{Cl}(r: 0.65)$ and $\mathrm{NH}_{4} \mathrm{NO}_{3}(r: 0.73)$ for $\mathrm{L}$.

High volume fractions of $\left(\mathrm{NH}_{4}\right)_{2} \mathrm{SO}_{4}$ and $\mathrm{NH}_{4} \mathrm{NO}_{3}$ may be attributed to $\mathrm{SO}_{x}, \mathrm{NO}_{x}$, and $\mathrm{NH}_{3}$ emissions due to power plant emissions and traffic. In the SA sub-branches (Fig. 4), the spike in $\kappa$ during the early morning (07:00-08:00) exhibited the sequence $\kappa_{(\mathrm{R} 3)}>\kappa_{(\mathrm{R} 2)}>\kappa_{(\mathrm{R} 1)}>=\kappa_{(\mathrm{L})}$, and the lower spike in late evening (18:00-22:00) exhibited the sequence $\mathrm{R} 3>\mathrm{R} 2<\mathrm{R} 1<\mathrm{L}$ and is attributed to $\mathrm{NH}_{4} \mathrm{Cl}$ formation. This implies that during the morning, $\mathrm{R} 3$ aerosols were most hygroscopic, while L aerosols were least hygroscopic, while after 09:00, L aerosols were most hygroscopic and R3 aerosols were the least hygroscopic. The flatter curve of $\kappa$ can be attributed to two factors: (a) the chloride contribution of distant trajectories decreased very steeply with time compared to the local emissions, and (b) $\kappa$ of $\mathrm{L}$ was also supplemented substantially by $\mathrm{NH}_{4} \mathrm{NO}_{3}$. Thus, the source activities by which the chemical properties of aerosols are shaped impacted the hygroscopicity parameter tremendously. This consequently impacted the size regime of aerosols available for activation and is discussed in the following section.

\subsection{Impact of governing parameters on $\mathrm{CCN}$ estimates of air masses}

$\mathrm{CCN}$ number concentration $\left(N_{\mathrm{CCN}}\right)$ for $\mathrm{SA}$ $(22526 \pm 13439)$ was higher compared to that in BB $(12526 \pm 5626)$ and AS $(11089 \pm 6650)$, where values $\left(\mathrm{cm}^{-3}\right)$ are given at $0.4 \%$ SS. Amongst the SA subbranches, $N_{\mathrm{CCN}}$ followed an increasing order, as $N_{\mathrm{CCN}(\mathrm{L})}$ $(18810 \pm 9434)<N_{\mathrm{CCN}(\mathrm{R} 3)} \quad(20469 \pm 10580)<N_{\mathrm{CCN}(\mathrm{R} 2)}$ $(23736 \pm 13739)<N_{\mathrm{CCN}(\mathrm{R} 1)}(24053 \pm 14743)$, while for the B branches, the order of increase in $N_{\mathrm{CCN}}\left(\mathrm{cm}^{-3}\right)$ was $N_{\mathrm{CCN}(\mathrm{B})} \quad(11699 \pm 4900)<N_{\mathrm{CCN} \text { (B.reg) }} \quad(14088 \pm 6506)$ at $0.4 \%$ SS. Correspondingly, the activated fractions $\left(a_{\mathrm{f}}\right)$ followed the sequence $a_{\mathrm{f}(\mathrm{SA})}(0.70 \pm 0.15)<a_{\mathrm{f}(\mathrm{BB})}$ $(0.64 \pm 0.17)<a_{\mathrm{f}(\mathrm{AS})}(0.55 \pm 0.18)$, wherein for SA subbranches, $a_{\mathrm{f}(\mathrm{R} 3)}(0.65 \pm 0.16)<a_{\mathrm{f}(\mathrm{R} 2)}(0.694 \pm 0.16)<a_{\mathrm{f}(\mathrm{L})}$ $(0.692 \pm 0.13)<a_{\mathrm{f}(\mathrm{R} 1)}(0.71 \pm 0.15)$, and for BB, $a_{\mathrm{f}(\mathrm{B} . \mathrm{reg})}$ $(0.62 \pm 0.16)<a_{\mathrm{f}(\mathrm{B})} \quad(0.65 \pm 0.18) \quad$ at $0.4 \% \quad$ SS. Mean
Table 3. Mean values of $\mathrm{CCN}$ number concentrations $\left(\mathrm{cm}^{-3}\right)$ at $0.1 \%, 0.4 \%$, and $0.8 \%$ SS for all clusters.

\begin{tabular}{lrr|rr|rr}
\hline \multirow{2}{*}{ Cluster } & \multicolumn{2}{c|}{ CCN at $0.1 \%$ SS } & \multicolumn{2}{c}{ CCN at $0.4 \%$ SS } & \multicolumn{2}{c}{ CCN at $0.8 \%$ SS } \\
\cline { 2 - 7 } & Mean & SD & Mean & SD & Mean & SD \\
\hline A & 3669 & 2480 & 11089 & 6650 & 15339 & 8149 \\
BB & 4558 & 1945 & 12526 & 5626 & 16329 & 7385 \\
SA & 10245 & 6352 & 22526 & 13439 & 27374 & 14902 \\
\hline B & 4469 & 1885 & 11699 & 4900 & 14892 & 5883 \\
B.reg & 4726 & 2043 & 14088 & 6506 & 19040 & 8993 \\
\hline L & 8200 & 4612 & 18810 & 9434 & 23161 & 10845 \\
R1 & 10921 & 6843 & 24053 & 14743 & 28914 & 16265 \\
R2 & 11318 & 6071 & 23736 & 13739 & 28926 & 15111 \\
R3 & 9555 & 6077 & 20469 & 10580 & 25971 & 11963 \\
\hline
\end{tabular}

$N_{\mathrm{CCN}}$ and $a_{\mathrm{f}}$ for all branches at $0.1 \%, 0.4 \%$, and $0.8 \%$ SS are detailed in Tables 3 and 4, respectively. The total number concentrations $\left(N_{\mathrm{CN}}\right.$ in $\left.\mathrm{cm}^{-3}\right)$ followed the sequence $N_{\mathrm{CN}(\mathrm{AS})}(20558 \pm 9654)<N_{\mathrm{CN}(\mathrm{BB})}$ $(20864 \pm 9731)<N_{\mathrm{CN}(\mathrm{SA})}$ $(31406 \pm 15168)$, and for $\mathrm{SA}, \quad N_{\mathrm{CN}(\mathrm{L})} \quad(27009 \pm 11651)<N_{\mathrm{CN}(\mathrm{R} 3)}$ $(30974 \pm 12223)<N_{\mathrm{CN}(\mathrm{R} 1)} \quad(32772 \pm 16475)<N_{\mathrm{CN}(\mathrm{R} 2)}$ (33 371 \pm 14989$)$, and $N_{\mathrm{CN}(\mathrm{B})}(19025 \pm 7704)<N_{\mathrm{CN} \text { (B.reg) }}$ $(24333 \pm 11956)$. Mean $N_{\mathrm{CN}}$ values for all branches are listed in Table S2.

High values of $N_{\mathrm{CCN}}$ for Delhi are consistent with other polluted regions in the world. The relevant statistics for two highly polluted sites, namely Beijing and Kanpur, are presented by Gunthe et al. (2011) and Bhattu and Tripathi (2015), respectively. $N_{\mathrm{CCN}}$ was $7660 \pm 3460$ and 900 27000 (in $\mathrm{cm}^{-3}$ ) at $0.46 \% \mathrm{SS}$ and in the range $0.18 \%$ $0.6 \% \mathrm{SS}$, respectively. The high $N_{\mathrm{CCN}}$ is consistent with the high $N_{\mathrm{CN}}$. Correspondingly, $N_{\mathrm{CN}}$ was $16800 \pm 9100$ and $\sim 50000\left(\mathrm{~cm}^{-3}\right)$. Even though high number concentrations of $\mathrm{CCN}$ and condensation nuclei $(\mathrm{CN})$ have been reported, the $a_{\mathrm{f}}$ was not seen to be so high. The $a_{\mathrm{f}}$ in Beijing was $0.54 \pm 0.23$ and $0.66 \pm 0.23$ at $0.46 \%$ SS and $0.86 \%$ SS, respectively. For Kanpur, $a_{\mathrm{f}}$ was reported as $\sim 0.018-0.54$ for $0.18 \%-0.60 \%$ SS. However for Delhi, the $a_{\mathrm{f}}$ ranged from 
Table 4. Mean activated fractions at $0.1 \%, 0.4 \%$, and $0.8 \%$ SS for all clusters.

\begin{tabular}{lrr|rr|rr}
\hline \multirow{2}{*}{ Cluster } & \multicolumn{2}{c|}{$a_{\mathrm{f}}$ at $0.1 \% \mathrm{SS}$} & \multicolumn{2}{|c|}{$a_{\mathrm{f}}$ at $0.4 \% \mathrm{SS}$} & \multicolumn{2}{c}{$a_{\mathrm{f}}$ at $0.8 \% \mathrm{SS}$} \\
\cline { 2 - 7 } & Mean & $\mathrm{SD}$ & Mean & SD & Mean & SD \\
\hline A & 0.19 & 0.09 & 0.55 & 0.18 & 0.75 & 0.15 \\
BB & 0.25 & 0.10 & 0.64 & 0.17 & 0.81 & 0.14 \\
SA & 0.33 & 0.13 & 0.70 & 0.15 & 0.86 & 0.10 \\
\hline B & 0.25 & 0.10 & 0.65 & 0.18 & 0.81 & 0.15 \\
B.reg & 0.23 & 0.10 & 0.62 & 0.16 & 0.80 & 0.12 \\
\hline L & 0.31 & 0.11 & 0.69 & 0.13 & 0.85 & 0.09 \\
R1 & 0.34 & 0.13 & 0.71 & 0.15 & 0.87 & 0.10 \\
R2 & 0.35 & 0.13 & 0.69 & 0.16 & 0.85 & 0.11 \\
R3 & 0.30 & 0.13 & 0.65 & 0.16 & 0.82 & 0.12 \\
\hline
\end{tabular}

0.19 for AS, at $0.1 \% \mathrm{SS}$, to 0.86 for R1, at $0.8 \% \mathrm{SS}$, implying that even at low SS, a considerably large number of particles were activated, and at high SS, almost all particles reached the activated state. It should be noted here that the statistics for Beijing and Kanpur correspond to the range (3$900 \mathrm{~nm})$ and $(14.6-680 \mathrm{~nm})$, while the estimates for Delhi are given in the $(10-560 \mathrm{~nm})$ range. This finding is also consistent with Wang and Chen (2019), which states that for Delhi, activation of a $0.1 \mu \mathrm{m}$ particle requires $\mathrm{SS} \sim 0.18 \pm 0.015 \%$, compared with $\sim 0.3 \%$ for Beijing; $0.28 \%-0.31 \%$ for Asia, Africa, and South America; and $\sim 0.22 \%$ for Europe and North America. The high activated fractions of aerosol can impact the precipitation patterns in Delhi and may be responsible for the short, intense precipitation events and decrease in overall rainfall. However, no study to date has validated this growing trend with $\mathrm{CCN}$ measurements or estimates, and this needs to be investigated in the future.

The $a_{\mathrm{f}}$ and $N_{\mathrm{CCN}}$ for all air masses increased as expected with an increase in supersaturation. The variation in $\mathrm{CCN}$ and the activated fraction with SS are shown in Figs. 5 and S3. The figures clearly show that even though $N_{\mathrm{CCN}}$ for SA was far greater compared to BB and AS, the activated fractions were fairly close. B.reg had higher $N_{\mathrm{CCN}}$ but a close $a_{\mathrm{f}}$ compared to B. Similarly, L had the lowest $N_{\mathrm{CCN}}$ among all SA branches but the highest $a_{\mathrm{f}}$. These features elucidate that many factors are at play and impact $N_{\mathrm{CCN}}$ and $a_{\mathrm{f}}$ differently. To determine the governing parameters impacting both $N_{\mathrm{CCN}}$ and $a_{\mathrm{f}}$, the diurnal patterns of $N_{\mathrm{CCN}}, a_{\mathrm{f}}$, and $D_{\mathrm{c}}$ at $0.1 \%$, $0.4 \%$, and $0.8 \% \mathrm{SS} ; N_{\mathrm{CN}}, N_{\text {Aitken }}$, and $N_{\text {Accumulation }} ; \kappa$; and geometric mean diameter (GMD) are shown in Figs. 6, S4, and S5.

The $N_{\mathrm{CCN}}$ curve for SA showed a sharp diurnal feature which was not as prominent for the other two. However, at noon, at $0.4 \%$ and $0.8 \% \mathrm{SS}$, while $N_{\mathrm{CCN}}$ dipped for SA, it rose for AS and BB (Fig. 6). Furthermore, with the increase in supersaturation, the dip in $\mathrm{CCN}$ of SA increased such that (a) at $0.1 \% \mathrm{SS}, \mathrm{SA}_{\mathrm{CCN}}>\mathrm{AS}_{\mathrm{CCN}}, \mathrm{BB}_{\mathrm{CCN}}$; (b) at
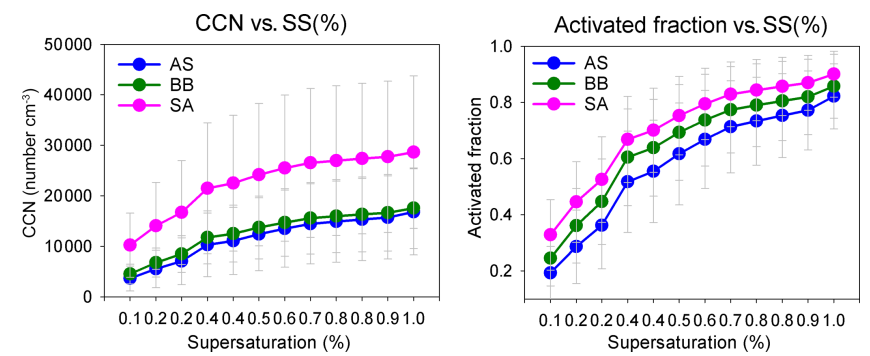

Figure 5. Variation in $\mathrm{CCN}$ and activated fraction with SS (\%) for $\mathrm{AS}, \mathrm{BB}$, and SA air masses.

$0.4 \% \mathrm{SS}, \mathrm{SA}_{\mathrm{CCN}} \cong \mathrm{AS}_{\mathrm{CCN}}, \mathrm{BB}_{\mathrm{CCN}}$; and (c) at $0.8 \% \mathrm{SS}$, $\mathrm{SA}_{\mathrm{CCN}}<\mathrm{BB}_{\mathrm{CCN}}$ and $\cong \mathrm{AS}_{\mathrm{CCN}}$. The explanation for this observation is that at $0.1 \% \mathrm{SS}$, the $\mathrm{CCN}$ was governed by the accumulation mode, but at $0.4 \%$ and $0.8 \%$ SS, it was governed more by the Aitken mode. It is the Aitken mode that dominantly governs the total number concentration, and hence it can be said that $\mathrm{CCN}$ is governed by $\mathrm{CN}$ at a higher SS and by the accumulation mode at low SS. This is because as supersaturation increases, $D_{\mathrm{c}}$ increases. At low SS, $D_{\mathrm{c}}$ is high $\left(D_{\mathrm{c}}>100 \mathrm{~nm}\right)$, almost always at a $0.1 \% \mathrm{SS}$, for all branches, as shown in Fig. 6d; hence the size distribution that is integrated to get the $\mathrm{CCN}$ involves the accumulation mode only. At $0.4 \% \mathrm{SS}$, the $D_{\mathrm{c}}$ was around $40-47 \mathrm{~nm}$; therefore a considerable fraction of the Aitken mode and accumulation mode was available for activation. At $0.8 \% \mathrm{SS}$, the $D_{\mathrm{c}}$ was $\sim 25-30 \mathrm{~nm}$; therefore, the contribution of the Aitken mode further increases and the accumulation mode is also available as usual. These findings are also true for BB branches (B and B.reg) and SA branches (L, R1, R2, and R3), as shown in Fig. S4. It is the low value of $D_{\mathrm{c}}$ relative to other places that is responsible for high $\mathrm{CCN}$. As explained in Sect. 3.4, $D_{\mathrm{c}}$ is largely associated with $\kappa$. The $D_{\mathrm{c}}$ at other places such as Kanpur varied from 50 to $200 \mathrm{~nm}$, for SS ranging from 0.18 to 0.60 (Bhattu and Tripathi, 2015), compared to which $D_{\mathrm{c}}$ for Delhi is lower $(17-142 \mathrm{~nm}$, for SS ranging from $0.1 \%$ to $0.8 \%$ ), implying that a larger regime is available for activation. It is pertinent to mention here that the dip in CCN for SA at midday and the peak at the same time for AS and BB can be attributed to the following. (a) The dip in $N_{\text {Accumulation }}$ for $\mathrm{SA}$ at midday was much more prominent compared to AS and BB. (b) At midday, the $N_{\text {Aitken for SA }}$ also decreased, while it increased for AS and BB. Thus, the dip in $N_{\mathrm{CCN}}$ was strengthened by the simultaneous dip of both the Aitken and accumulation modes, while the peak in $N_{\mathrm{CCN}}$ for AS and BB was a manifestation of the dominant peak in Aitken modes. Similar features were also exhibited for sub-branches of BB and SA. A deeper insight reveals that the dip in number concentration at midday for SA was most aptly seen in the diurnal pattern of POA (which is the most dominant $\mathrm{NRPM}_{1}$ species) and, to quite a good extent, in other $\mathrm{NRPM}_{1}$ species barring the $\mathrm{SO}_{4}^{2-}$ ion. Similarly, the peak in the Aitken mode for AS and BB can be attributed 

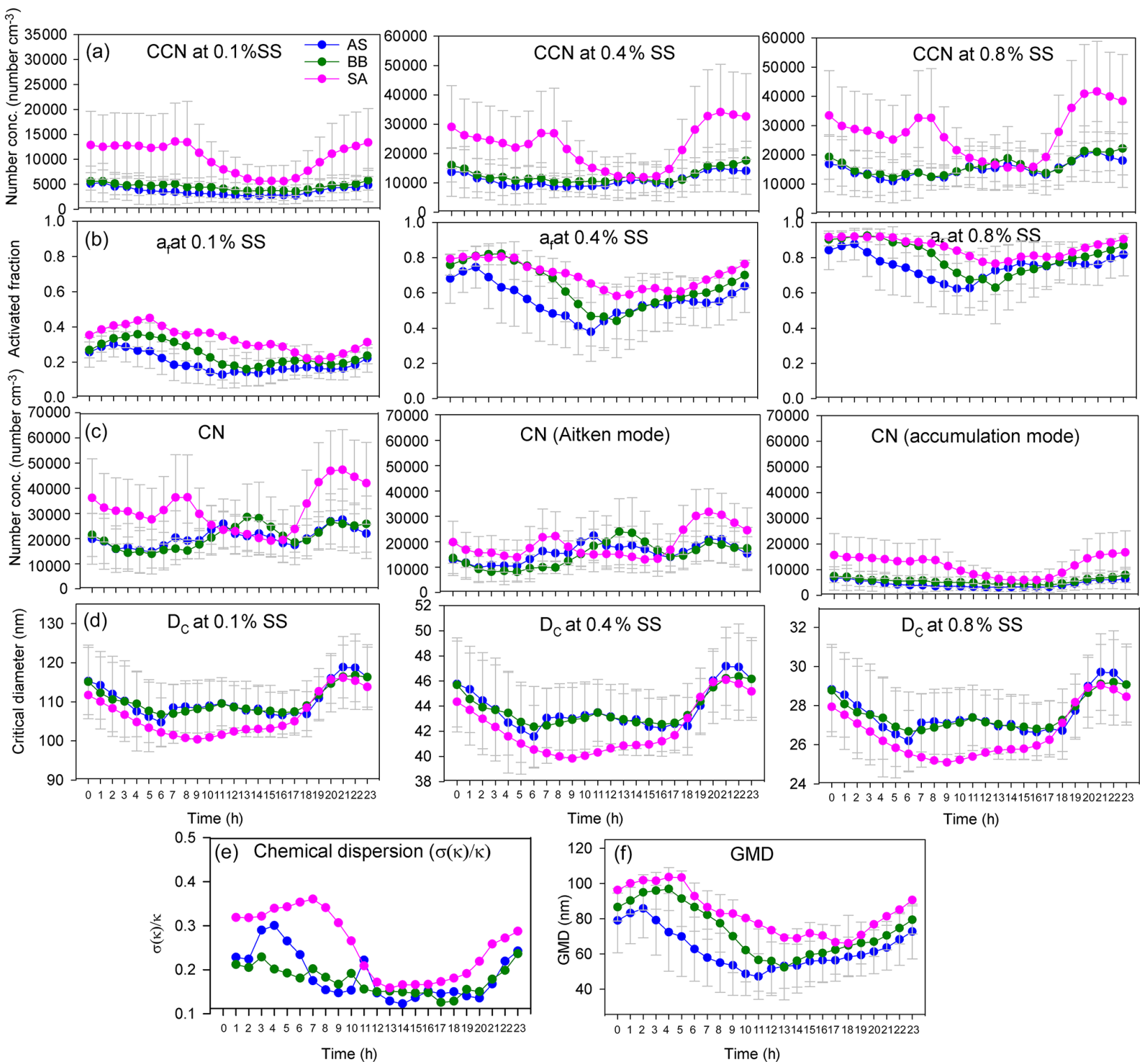

Figure 6. Diurnal variation in (a) $N_{\mathrm{CCN}}$ at $0.1 \%, 0.4 \%$, and $0.8 \% \mathrm{SS}$; (b) $a_{\mathrm{f}}$ at $0.1 \%, 0.4 \%$, and $0.8 \% \mathrm{SS}$; (c) $N_{\mathrm{CN}}, N_{\mathrm{Aitken}}$, and $N_{\text {Accumulation; }}$ (d) $D_{\mathrm{c}}$ at $0.1 \%, 0.4 \%$, and $0.8 \% \mathrm{SS}$; (e) chemical dispersion; and (f) GMD for AS, BB, and SA air masses.

to $\mathrm{NH}_{4}^{+}, \mathrm{SO}_{4}^{2-}$, and OOA concentrations (the dominating species in the respective branches). Thus, the source activities and trajectory pathways impact $\mathrm{CCN}$ concentration at the receptor site.

The diurnal pattern for $a_{\mathrm{f}}$ showed a dip in the midday hours for all the air masses even though $N_{\mathrm{CCN}}$ at midday for $\mathrm{AS}$ and $\mathrm{BB}$ peaked during midday hours. The time of dip in $a_{\mathrm{f}}$ (more prominent at $0.4 \%$ and $0.8 \% \mathrm{SS}$ ) occurred earlier for AS compared to that for BB and SA (Fig. 6). This was governed by the time of dip in the GMD of the three branches. The GMD diurnal variation was very similar to $a_{\mathrm{f}}$, and the $r^{2}$ values between GMD and $a_{\mathrm{f}}$ listed in Table S3 also point to the same result. Thus, even though a dip in $D_{\mathrm{c}}$ should correspond with an increase in $a_{\mathrm{f}}$ and vice versa, this does not usually happen, as the change in $D_{\mathrm{c}}$ is less compared to the shift in size distribution such that not only the highest number concentration values but also the diameter at which this occurs change, thereby changing the number available for activation. For example, in Fig. 7 two different size distributions for the AS air mass at 02:00 and 11:00 are compared. At 02:00 and 11:00, the following characteristics were noted: (a) $\mathrm{GMD}_{02: 00}: 83.78 \pm$ $16.58 \mathrm{~nm}$ (GSD - geometric standard deviation), which is considerably higher than $\mathrm{GMD}_{11: 00}: 47.18 \pm 13.01 \mathrm{~nm}$; (b) $\mathrm{GSD}_{02: 00}: 1.69 \pm 0.13 \mathrm{~nm}$, which is nearly the same as $\mathrm{GSD}_{11: 00}: 1.62 \pm 0.14 \mathrm{~nm}$; (c) $D_{\mathrm{c} 02: 00}: 44.45 \pm 3.83 \mathrm{~nm}$, 


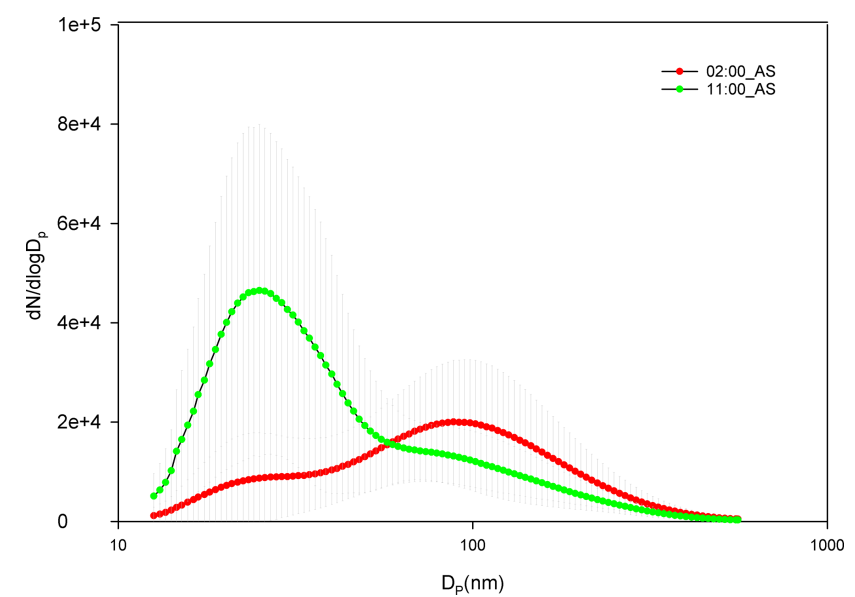

Figure 7. Comparison of two size distribution profiles at different times of day for AS branch at 02:00 and 11:00.

which is slightly higher than $D_{\mathrm{c} 11: 00}: 43.48 \pm 2.28 \mathrm{~nm}$ (at $0.4 \% \mathrm{SS}$ ); (d) $\mathrm{CN}_{02: 00}: 15849 \pm 9269 \mathrm{~cm}^{-3}$, which is lower than $\mathrm{CN}_{11: 00}: 25873 \pm 9840 \mathrm{~cm}^{-3}$; (e) CN_Aitken $02: 00$ : $9819 \pm 5945 \mathrm{~cm}^{-3}$, which is lower than CN_Aitken $11: 00$ : $22376 \pm 9693 \mathrm{~cm}^{-3}$; (f) CN_Accumulation $02: 00: 5729 \pm$ $3684 \mathrm{~cm}^{-3}$, which is higher than CN_Accumulation $11: 00$ : $3311 \pm 1569 \mathrm{~cm}^{-3}$; $(\mathrm{g}) a_{\mathrm{f} 02: 00}: 0.75 \pm 0.12$, which is considerably higher than $a_{\mathrm{f} 11: 00}: 0.38 \pm 0.17$ at $0.4 \% \mathrm{SS}$; and (h) $\mathrm{CCN}_{02: 00}: 11595 \pm 6710 \mathrm{~cm}^{-3}$, which is higher than $\mathrm{CCN}_{11: 00}: 8946 \pm 3899 \mathrm{~cm}^{-3}$ at $0.4 \% \mathrm{SS}$. The $a_{\mathrm{f}}$ at $02: 00$ is higher than that at 11:00. A $D_{\mathrm{c}}$ decrease should correspond to a CCN increase, but the magnitude of $\Delta D_{\mathrm{c}}=0.97 \mathrm{~nm}$ is very small. The decrease in GMD $(\Delta \mathrm{GMD}=36.6 \mathrm{~nm})$, on the other hand, is very high, with negligible changes in GSD. At 02:00, since $D_{\text {c }}$ was considerably less than GSD, most of the particles are counted for activation. At 11:00, since $D_{\mathrm{c}}$ and GMD were very close, nearly $50 \%$ of particles are not available for activation. The very high Aitken mode concentration at 11:00 (higher than that at 02:00) was not available for activation at both the times. Thus, $N_{\mathrm{CCN}}$ here is governed by the accumulation mode, which was higher at 02:00, thus making $N_{\mathrm{CCN}}$ higher. In this scenario, $N_{\mathrm{CCN}}$ and $a_{\mathrm{f}}$ go hand in hand. However, there also exists a second possibility; e.g. for the SA branch, $N_{\mathrm{CCN}}$, at $0.4 \% \mathrm{SS}$, at 08:00 is higher than that at 05:00, while the $a_{\mathrm{f}}$ at 08:00 is lower than that at 05:00 (Fig. 6). $N_{\mathrm{CCN}}$ was governed at these times by the Aitken mode, which was higher at 08:00, while $a_{\mathrm{f}}$ is governed by the GMD, which was lower at 08:00. Therefore, it is established that $\mathrm{CCN}$ is governed by $\mathrm{CN}$ (dominantly by either the Aitken or accumulation mode as the case may be), while the $a_{\mathrm{f}}$ is governed by GMD.

At this junction, it is also pertinent to mention how chemical dispersion and parameters governing $\mathrm{CCN}$ are interconnected. The standard deviation of $\kappa(\sigma(\kappa))$ around $\kappa$ is often used as an estimate of the degree of heterogeneity (chemical dispersion) of particles (Psichoudaki et al., 2018; Lance et al., 2013). The chemical dispersion for all air masses and their sub-branches is shown in Figs. 6, S4, and S5. The chemical dispersion for the SA air mass during the early hours (06:00-08:00) coincided with chloride emissions, and late at night, after 20:00, it coincided with POA and OOA emissions. During the time of high chloride emissions, $\kappa$ also peaked, since inorganics are associated with high hygroscopicity, while during the late hours, $\kappa$ dropped due to an increase in organics associated with low hygroscopicity. The diurnal patterns of the activated fraction, GMD, and chemical dispersion were also similar. This implies that higher heterogeneity shifts GMD towards a high value, thereby increasing the available regime for activation, and vice versa. There was no discernible pattern noted for the other air masses.

It is hereby established that aerosol physical and chemical properties, and their time evolution, are tightly linked with each other. The indirect impact of chemical composition on CCN and $a_{\mathrm{f}}$ is manifested in two ways: (a) $\mathrm{NRPM}_{1}$ species impact the diurnal patterns of Aitken and accumulation modes, which in turn impact $\mathrm{CCN}$, and (b) $\mathrm{NRPM}_{1}$ species impact $\kappa$, hence subsequently $\mathrm{CCN}$, by impacting the size regime available for activation.

\section{Conclusion}

Long-term measurements of $\mathrm{NRPM}_{1}$ species and size distribution data were carried out in New Delhi. The air masses originated from SA (L, R1, R2, and R3), BB (B and B.reg), and AS. $\kappa$ was estimated using the mixing rule, and the bulk $\kappa$ was assumed for the entire size distribution. Using $\kappa$ and size distribution data, $\mathrm{CCN}$ estimates were obtained. The SA air mass was the most contaminated air mass, followed by $\mathrm{BB}$ and then AS. This resulted in higher $\mathrm{NRPM}_{1}, N_{\mathrm{CN}}$ (both Aitken and accumulation modes), $N_{\mathrm{CCN}}$, and $a_{\mathrm{f}}$ for SA, followed by those in $\mathrm{BB}$ and then those in AS. The most dominant salts turned out to be $\left(\mathrm{NH}_{4}\right)_{2} \mathrm{SO}_{4}$ for AS, $\left(\mathrm{NH}_{4}\right)_{2} \mathrm{SO}_{4}$ and $\mathrm{NH}_{4} \mathrm{NO}_{3}$ for $\mathrm{BB}$, and $\mathrm{NH}_{4} \mathrm{Cl}$ for $\mathrm{SA}$. The AS, B, and $\mathrm{L}$ branches were completely neutralized, while B.reg, R1, R2, and R3 were partially neutralized. The diurnal variations in $\mathrm{NRPM}_{1}$ species were governed by source activities' aerosol precursors, like $\mathrm{SO}_{x}, \mathrm{NO}_{x}, \mathrm{NH}_{3}, \mathrm{O}_{3}$, and $\mathrm{O}_{x}$. The high $\mathrm{PM}_{1}$ concentration for Delhi, which exceeds the National Ambient Air Quality Standards, can be mitigated only by controlling both the primary emissions and precursors. To address the situation justly, the following is lacking: (a) data listing measurements of $\mathrm{PM}_{1}$ emissions from various industries in India and Asia, (b) a description of the chemical constituents of aerosol that are emitted, both qualitatively and quantitatively, and (c) a definition of emission limits and compliance with them.

The mean $\kappa \sim 0.3$ was the same for all air masses, with the diurnal variation in $\kappa$ governed by chemical species and, thus, source activities. The $\kappa$ diurnal trends impacted the $D_{\mathrm{c}}$ diurnal trend, which in turn affected the available regime for 
activation. The $N_{\mathrm{CCN}}$ diurnal patterns were driven by the accumulation mode at a lower SS and Aitken mode with an increase in SS, depending upon $D_{\mathrm{c}}$, which decreases with an increase in SS. The $D_{\mathrm{c}}$ obtained for Delhi was lower than that seen at other places in the IGP, for example, Kanpur. The activated fraction for Delhi was very high $(0.71 \pm 0.15$ at $0.4 \% \mathrm{SS}$ for R1), with the means of activated fractions varying between 0.19 and 0.87 , for SS varying from $0.1 \%$ to $0.8 \%$, whereby their diurnal patterns were governed by GMD. A CCN measurement study with a CCN counter in the future can help verify the estimates, and a closure ratio may be determined. However, in the absence of long-term cloud condensation nuclei counter (CCNC) measurements, the importance of these findings cannot be neglected. These results can serve as valuable inputs to GCMs to better quantify precipitation. The high $\mathrm{NRPM}_{1}$ loading and activated fractions are bound to significantly impact precipitation over Delhi, impact the aerosol radiation budget, and have indirect effects and need to be investigated thoroughly in the future. These investigations may answer the short intense precipitation events occurring over Delhi and the decrease in the overall rainfall over the past half-century.

Data availability. All data pertaining to this study can be downloaded from http://web.iitd.ac.in/ gazala/rawdata_arubetal2020. xlsx (Arub et al., 2020).

Supplement. The supplement related to this article is available online at: https://doi.org/10.5194/acp-20-6953-2020-supplement.

Author contributions. LHR, JSP, GH, and ZA designed the study. ZA, SG, and SB carried out the data collection. ZA carried out data processing and analysis. ZA and GH carried out the interpretation of the results. ZA wrote the paper and was assisted by SB, LHR, and $\mathrm{GH}$ in reviewing the paper.

Competing interests. The authors declare that they have no conflict of interest.

Acknowledgements. We are thankful to the Indian Institute of Technology Delhi (IITD) for institutional support. We are grateful to all students and staff members of the Aerosol Research and Characterization Laboratory at IITD for their constant support. We are thankful to Philip Croteau (Aerodyne Research) for always providing timely technical support for the ACSM.

Review statement. This paper was edited by Veli-Matti Kerminen and reviewed by two anonymous referees.

\section{References}

Andreae, M. O. and Rosenfeld, D.: Aerosol-cloudprecipitation interactions. Part 1 . The nature and sources of cloud-active aerosols, Earth-Sci. Rev., 89, 13-41, https://doi.org/10.1016/j.earscirev.2008.03.001, 2008.

Arub, Z., Bhandari, S., Gani, S., Apte, J. S., Hildebrandt Ruiz, L., and Habib, G.: rawdata_arubetal2020.xlsx, available at: http:// web.iitd.ac.in/ gazala/rawdata_arubetal2020.xlsx, last access: 6 June 2020.

Asa-Awuku, A., Moore, R. H., Nenes, A., Bahreini, R., Holloway, J. S., Brock, C. A., Middlebrook, A. M., Ryerson, T. B., Jimenez, J. L., Decarlo, P. F., Hecobian, A., Weber, R. J., Stickel, R., Tanner, D. J., and Huey, L. G.: Airborne cloud condensation nuclei measurements during the 2006 Texas Air Quality Study, J. Geophys. Res.-Atmos., 116, 1-18, https://doi.org/10.1029/2010JD014874, 2011.

Atkinson, R., Baulch, D. L., Cox, R. A., Crowley, J. N., Hampson, R. F., Hynes, R. G., Jenkin, M. E., Rossi, M. J., Troe, J., and IUPAC Subcommittee: Evaluated kinetic and photochemical data for atmospheric chemistry: Volume II - gas phase reactions of organic species, Atmos. Chem. Phys., 6, 3625-4055, https://doi.org/10.5194/acp-6-3625-2006, 2006.

Bhandari, S., Gani, S., Patel, K., Wang, D. S., Soni, P., Arub, Z., Habib, G., Apte, J. S., and Hildebrandt Ruiz, L.: Sources and atmospheric dynamics of organic aerosol in New Delhi, India: insights from receptor modeling, Atmos. Chem. Phys., 20, 735752, https://doi.org/10.5194/acp-20-735-2020, 2020.

Bhattu, D. and Tripathi, S. N.: Inter-seasonal variability in sizeresolved CCN properties at Kanpur, India, Atmos. Environ., 85, 161-168, https://doi.org/10.1016/j.atmosenv.2013.12.016, 2014.

Bhattu, D. and Tripathi, S. N.: CCN closure study: Effects of aerosol chemical composition and mixing state, J. Geophys Res.-Atmos., 120, 766-783, https://doi.org/10.1002/2014JD021978, 2015.

Bi, X., Zhang, G., Li, L., Wang, X., Li, M., Sheng, G., Fu, J., and Zhou, Z.: Mixing state of biomass burning particles by single particle aerosol mass spectrometer in the urban area of PRD, China, Atmos. Environ., 45, 3447-3453, https://doi.org/10.1016/j.atmosenv.2011.03.034, 2011.

Boucher, O., Randall, D., Artaxo, P., Bretherton, C., Feingold, G., Forster, P., Kerminen, V.-M., Kondo, Y., Liao, H., Lohmann, U., Rasch, P., Satheesh, S. K., Sherwood, S., Stevens, B., and Zhang, X. Y.: Clouds and Aerosols, in: Climate Change 2013: The Physical Science Basis. Contribution of Working Group I to the Fifth Assessment Report of the Intergovernmental Panel on Climate Change, edited by: Stocker, T. F., Qin, D., Plattner, G.-K., Tignor, M., Allen, S. K., Boschung, J., Nauels, A., Xia, Y., Bex, V., and Midgley, P. M., Cambridge University Press, Cambridge, UK and New York, NY, USA, 2013.

Bougiatioti, A., Fountoukis, C., Kalivitis, N., Pandis, S. N., Nenes, A., and Mihalopoulos, N.: Cloud condensation nuclei measurements in the marine boundary layer of the Eastern Mediterranean: CCN closure and droplet growth kinetics, Atmos. Chem. Phys., 9, 7053-7066, https://doi.org/10.5194/acp-9-7053-2009, 2009.

Bougiatioti, A., Nenes, A., Fountoukis, C., Kalivitis, N., Pandis, S. N., and Mihalopoulos, N.: Size-resolved CCN distributions and activation kinetics of aged continental and marine aerosol, Atmos. Chem. Phys., 11, 8791-8808, https://doi.org/10.5194/acp11-8791-2011, 2011. 
Braga, R. C., Rosenfeld, D., Weigel, R., Jurkat, T., Andreae, M. O., Wendisch, M., Pöschl, U., Voigt, C., Mahnke, C., Borrmann, S., Albrecht, R. I., Molleker, S., Vila, D. A., Machado, L. A. T., and Grulich, L.: Further evidence for CCN aerosol concentrations determining the height of warm rain and ice initiation in convective clouds over the Amazon basin, Atmos. Chem. Phys., 17, 1443314456, https://doi.org/10.5194/acp-17-14433-2017, 2017.

Brock, C. A., Wagner, N. L., Anderson, B. E., Beyersdorf, A., Campuzano-Jost, P., Day, D. A., Diskin, G. S., Gordon, T. D., Jimenez, J. L., Lack, D. A., Liao, J., Markovic, M. Z., Middlebrook, A. M., Perring, A. E., Richardson, M. S., Schwarz, J. P., Welti, A., Ziemba, L. D., and Murphy, D. M.: Aerosol optical properties in the southeastern United States in summer Part 2: Sensitivity of aerosol optical depth to relative humidity and aerosol parameters, Atmos. Chem. Phys., 16, 5009-5019, https://doi.org/10.5194/acp-16-5009-2016, 2016.

Chakraborty, A., Bhattu, D., Gupta, T., Tripathi, S. N., and Canagaratna, M. R.: Real-time measurements of ambient aerosols in a polluted Indian city: Sources, characteristics, and processing of organic aerosols during foggy and nonfoggy periods, J. Geophys. Res.-Atmos., 120, 9006-9019, https://doi.org/10.1002/2015JD023419, 2015.

Chakraborty, A., Gupta, T., and Tripathi, S. N.: Chemical composition and characteristics of ambient aerosols and rainwater residues during Indian summer monsoon: Insight from aerosol mass spectrometry, Atmos. Environ., 136, 144-155, https://doi.org/10.1016/j.atmosenv.2016.04.024, 2016.

Chen, Y., Wild, O., Wang, Y., Ran, L., Teich, M., Größ, J., Wang, L., Spindler, G., Herrmann, H., van Pinxteren, D., McFiggans, G., and Wiedensohler, A.: The influence of impactor size cut-off shift caused by hygroscopic growth on particulate matter loading and composition measurements, Atmos. Environ., 195, 141-148, https://doi.org/10.1016/j.atmosenv.2018.09.049, 2018.

Cheney, J. L., Conner, W. D., Bennett, R. L., Duke, D. L., and Walters, C. L.: Formation of a detached plume from a cement plant, NTIS, Springfield, VA, USA, 1983.

Derwent, R. G., Ryall, D. B., Jennings, S. G., Spain, T. G., and Simmonds, P. G.: Black carbon aerosol and carbon monoxide in European regionally polluted air masses at Mace Head, Ireland during 1995-1998, Atmos. Environ., 35, 6371-6378, https://doi.org/10.1016/S1352-2310(01)00394-6, 2001.

Draxler, R. R. and Rolph, G. D.: HYSPLIT (HYbrid SingleParticle Lagrangian Integrated Trajectory) model access via NOAA ARL READY website, NOAA Air Resources Laboratory, Silver Spring, MD, 25, available at: http://ready.arl.noaa. gov/HYSPLIT.php (last access: 18 May 2020), 2003.

Du, H. H., Kong, L. D., Cheng, T., Chen, J., Yang, X., Zhang, R., Han, Z., Yan, Z., and Ma, Y.: Insights into ammonium particle-to-gas conversion: non-sulfate ammonium coupling with nitrate and chloride, Aerosol Air Qual. Res., 10, 589-595, https://doi.org/10.4209/aaqr.2010.04.0034, 2010.

Dusek, U., Frank, G. P., Curtius, J., Drewnick, F., Schneider, J., Kürten, A., Rose, D., Andreae, M. O., Borrmann, S., and Pöschl, U.: Enhanced organic mass fraction and decreased hygroscopicity of cloud condensation nuclei (CCN) during new particle formation events, Geophys. Res. Lett., 37, https://doi.org/10.1029/2009GL040930, 2010.

Engelhart, G. J., Hennigan, C. J., Miracolo, M. A., Robinson, A. L., and Pandis, S. N.: Cloud condensation nuclei activ- ity of fresh primary and aged biomass burning aerosol, Atmos. Chem. Phys., 12, 7285-7293, https://doi.org/10.5194/acp12-7285-2012, 2012.

Erickson, R. E., Yates, L. M., Clark, R. L., and McEwen, D.: The reaction of sulfur dioxide with ozone in water and its possible atmospheric significance, Atmos. Environ., 11, 813-817, https://doi.org/10.1016/0004-6981(77)90043-9, 1977.

Ervens, B., Turpin, B. J., and Weber, R. J.: Secondary organic aerosol formation in cloud droplets and aqueous particles (aqSOA): a review of laboratory, field and model studies, Atmos. Chem. Phys., 11, 11069-11102, https://doi.org/10.5194/acp-1111069-2011, 2011.

Esri, Garmin International: World Countries (Generalized), available at: https://www.arcgis.com/home/item.html? $\mathrm{id}=170 \mathrm{~b} 5 \mathrm{e} 6529064 \mathrm{~b} 8 \mathrm{~d} 9275168687880359$ (last access: 17 May 2020), 2010.

Fuzzi, S., Decesari, S., Facchini, M. C., Cavalli, F., Emblico, L., Mircea, M., Andreae, M. O., Trebs, I., Hoffer, A., Guyon, P., Artaxo, P., Rizzo, L. V., Lara, L. L., Pauliquevis, T., Maenhaut, W., Raes, N., Chi, X., Mayol-Bracero, O. L., Soto-García, L. L., Claeys, M., Kourtchev, I., Rissler, J., Swietlicki, E., Tagliavini, E., Schkolnik, G., Falkovich, A. H., Rudich, Y., Fisch, G., and Gatti, L. V.: Overview of the inorganic and organic composition of size-segregated aerosol in Rondonia, Brazil, from the biomassburning period to the onset of the wet season, J. Geophys. Res.Atmos., 112, https://doi.org/10.1029/2005JD006741, 2007.

Gandhi, H. S. and Shelef, M.: Effects of sulphur on noble metal automotive catalysts, Appl. Catal., 77, 175-186, https://doi.org/10.1016/0166-9834(91)80063-3, 1991.

Gani, S., Bhandari, S., Seraj, S., Wang, D. S., Patel, K., Soni, P., Arub, Z., Habib, G., Hildebrandt Ruiz, L., and Apte, J. S.: Submicron aerosol composition in the world's most polluted megacity: the Delhi Aerosol Supersite study, Atmos. Chem. Phys., 19, 6843-6859, https://doi.org/10.5194/acp-19-6843-2019, 2019.

Gaur, A., Tripathi, S. N., Kanawade, V. P., Tare, V., and Shukla, S. P.: Four-year measurements of trace gases $\left(\mathrm{SO}_{2}, \mathrm{NO}_{x}, \mathrm{CO}\right.$, and $\mathrm{O}_{3}$ ) at an urban location, Kanpur, in Northern India, J. Atmos. Chem., 71, 283-301, https://doi.org/10.1007/s10874-014-92958, 2014

Guhathakurta, P., Rajeevan, M., Sikka, D. R., and Tyagi, A.: Observed changes in southwest monsoon rainfall over India during 1901-2011, Int. J. Climatol., 35, 1881-1898, https://doi.org/10.1002/joc.4095, 2015.

Gunn, R. and Phillips, B. B.: An experimental investigation of the effect of air pollution on the initiation of rain, J. Meteorol., 14, 272-280, https://doi.org/10.1175/15200469(1957)014<0272:AEIOTE>2.0.CO;2, 1957.

Gunthe, S. S., King, S. M., Rose, D., Chen, Q., Roldin, P., Farmer, D. K., Jimenez, J. L., Artaxo, P., Andreae, M. O., Martin, S. T., and Pöschl, U.: Cloud condensation nuclei in pristine tropical rainforest air of Amazonia: size-resolved measurements and modeling of atmospheric aerosol composition and CCN activity, Atmos. Chem. Phys., 9, 7551-7575, https://doi.org/10.5194/acp9-7551-2009, 2009.

Gunthe, S. S., Rose, D., Su, H., Garland, R. M., Achtert, P., Nowak, A., Wiedensohler, A., Kuwata, M., Takegawa, N., Kondo, Y., Hu, M., Shao, M., Zhu, T., Andreae, M. O., and Pöschl, U.: Cloud condensation nuclei $(\mathrm{CCN})$ from fresh and aged air pollution in 
the megacity region of Beijing, Atmos. Chem. Phys., 11, 1102311039, https://doi.org/10.5194/acp-11-11023-2011, 2011.

Habib, G., Venkataraman, C., Chiapello, I., Ramachandran, S., Boucher, O., and Reddy, M. S.: Seasonal and interannual variability in absorbing aerosols over India derived from TOMS: Relationship to regional meteorology and emissions, Atmos. Environ., 40, 1909-1921, https://doi.org/10.1016/j.atmosenv.2005.07.077, 2006.

Harrison, R. M. and Pio, C. A.: Major ion composition and chemical associations of inorganic atmospheric aerosols, Environ. Sci. Technol., 17, 169-174, https://doi.org/10.1021/es00109a009, 1983.

Haynes, W. M., Lide, D. R., and Bruno, T. J. (Eds.): CRC Handbook of Chemistry and Physics, 95th Edn., CRC press, Florida, USA, 2014.

Ho, K. F., Lee, S. C., Guo, H., and Tsai, W. Y.: Seasonal and diurnal variations of volatile organic compounds (VOCs) in the atmosphere of Hong Kong, Sci. Total Environ., 322, 155-166, https://doi.org/10.1016/j.scitotenv.2003.10.004, 2004.

Hong, J., Häkkinen, S. A. K., Paramonov, M., Äijälä, M., Hakala, J., Nieminen, T., Mikkilä, J., Prisle, N. L., Kulmala, M., Riipinen, I., Bilde, M., Kerminen, V.-M., and Petäjä, T.: Hygroscopicity, $\mathrm{CCN}$ and volatility properties of submicron atmospheric aerosol in a boreal forest environment during the summer of 2010, Atmos. Chem. Phys., 14, 4733-4748, https://doi.org/10.5194/acp14-4733-2014, 2014.

Jaiprakash, Singhai, A., Habib, G., Raman, R. S., and Gupta, T.: Chemical characterization of $\mathrm{PM}_{1.0}$ aerosol in Delhi and source apportionment using positive matrix factorization, Environ. Sci. Pollut. R., 24, 445-462, https://doi.org/10.1007/s11356016-7708-8, 2017.

Kalapureddy, M. C. R., Kaskaoutis, D. G., Ernest Raj, P., Devara, P. C. S., Kambezidis, H. D., Kosmopoulos, P. G., and Nastos, P. T.: Identification of aerosol type over the Arabian Sea in the premonsoon season during the Integrated Campaign for Aerosols, Gases and Radiation Budget (ICARB), J. Geophys. Res.-Atmos., 114, D17203, https://doi.org/10.1029/2009JD011826, 2009.

Kaneyasu, N., Yoshikado, H., Mizuno, T., Sakamoto, K., and Soufuku, M.: Chemical forms and sources of extremely high nitrate and chloride in winter aerosol pollution in the Kanto Plain of Japan, Atmos. Environ., 33, 1745-1756, https://doi.org/10.1016/S1352-2310(98)00396-3, 1999.

Lance, S., Raatikainen, T., Onasch, T. B., Worsnop, D. R., Yu, X.Y., Alexander, M. L., Stolzenburg, M. R., McMurry, P. H., Smith, J. N., and Nenes, A.: Aerosol mixing state, hygroscopic growth and cloud activation efficiency during MIRAGE 2006, Atmos. Chem. Phys., 13, 5049-5062, https://doi.org/10.5194/acp-135049-2013, 2013.

Lee, S. Y., Gan, C., and Chew, B. N.: Visibility deterioration and hygroscopic growth of biomass burning aerosols over a tropical coastal city: a case study over Singapore's airport, Atmos. Sci. Lett., 17, 624-629, https://doi.org/10.1002/asl.712, 2016.

Leena, P. P., Pandithurai, G., Anilkumar, V., Murugavel, P., Sonbawne, S. M., and Dani, K. K.: Seasonal variability in aerosol, $\mathrm{CCN}$ and their relationship observed at a high altitude site in Western Ghats, Meteorol. Atmos. Phys., 128, 143-153, https://doi.org/10.1007/s00703-015-0406-0, 2016.

Leng, C., Zhang, Q., Zhang, D., Xu, C., Cheng, T., Zhang, R., Tao, J., Chen, J., Zha, S., Zhang, Y., Li, X., Kong, L., and Gao, W.:
Variations of cloud condensation nuclei $(\mathrm{CCN})$ and aerosol activity during fog-haze episode: a case study from Shanghai, Atmos. Chem. Phys., 14, 12499-12512, https://doi.org/10.5194/acp-1412499-2014, 2014.

Liu, X., Zhang, Y., Cheng, Y., Hu, M., and Han, T.: Aerosol hygroscopicity and its impact on atmospheric visibility and radiative forcing in Guangzhou during the 2006 PRIDE-PRD campaign, Atmos. Environ., 60, 59-67, https://doi.org/10.1016/j.atmosenv.2012.06.016, 2012.

Moorthy, K. K., Satheesh, S. K., Babu, S. S., and Dutt, C. B. S.: Integrated campaign for aerosols, gases and radiation budget (ICARB): an overview, J. Earth Syst. Sci., 117, 243-262, https://doi.org/10.1007/s12040-008-0029-7, 2008.

Nair, V. S., Moorthy, K. K., Babu, S. S., Narasimhulu, K., Reddy, L. S. S., Reddy, R. R., Gopal, K. R., Sreekanth, V., Madhavan, B. L., and Niranjan, K.: Size segregated aerosol mass concentration measurements over the Arabian Sea during ICARB, J. Earth Syst. Sci., 117, 315-323, https://doi.org/10.1007/s12040-008-0034-x, 2008a.

Nair, V. S., Babu, S. S., and Moorthy, K. K.: Aerosol characteristics in the marine atmospheric boundary layer over the Bay of Bengal and Arabian Sea during ICARB: Spatial distribution and latitudinal and longitudinal gradients, J. Geophys. Res.-Atmos., 113, D15208, https://doi.org/10.1029/2008JD009823, 2008b.

Nault, B. A., Campuzano-Jost, P., Day, D. A., Schroder, J. C., Anderson, B., Beyersdorf, A. J., Blake, D. R., Brune, W. H., Choi, Y., Corr, C. A., de Gouw, J. A., Dibb, J., DiGangi, J. P., Diskin, G. S., Fried, A., Huey, L. G., Kim, M. J., Knote, C. J., Lamb, K. D., Lee, T., Park, T., Pusede, S. E., Scheuer, E., Thornhill, K. L., Woo, J.-H., and Jimenez, J. L.: Secondary organic aerosol production from local emissions dominates the organic aerosol budget over Seoul, South Korea, during KORUS-AQ, Atmos. Chem. Phys., 18, 17769-17800, https://doi.org/10.5194/acp-18-177692018, 2018.

Nenes, A., Pandis, S. N., and Pilinis, C.: ISORROPIA: A new thermodynamic equilibrium model for multiphase multicomponent inorganic aerosols, Aquat. Geochem., 4, 123-152, https://doi.org/10.1023/A:1009604003981, 1998.

Ng, N. L., Canagaratna, M. R., Jimenez, J. L., Zhang, Q., Ulbrich, I. M., and Worsnop, D. R.: Real-time methods for estimating organic component mass concentrations from aerosol mass spectrometer data, Environ. Sci. Technol., 45, 910-916, https://doi.org/10.1021/es102951k, 2010.

Padró, L. T., Moore, R. H., Zhang, X., Rastogi, N., Weber, R. J., and Nenes, A.: Mixing state and compositional effects on CCN activity and droplet growth kinetics of size-resolved $\mathrm{CCN}$ in an urban environment, Atmos. Chem. Phys., 12, 10239-10255, https://doi.org/10.5194/acp-12-10239-2012, 2012.

Pan, Y., Tian, S., Liu, D., Fang, Y., Zhu, X., Zhang, Q., Zheng, B., Michalski, G., and Wang, Y.: Fossil fuel combustion-related emissions dominate atmospheric ammonia sources during severe haze episodes: Evidence from ${ }^{15} \mathrm{~N}$-stable isotope in sizeresolved aerosol ammonium, Environ. Sci. Technol., 50, 80498056, https://doi.org/10.1021/acs.est.6b00634, 2016.

Petters, M. D. and Kreidenweis, S. M.: A single parameter representation of hygroscopic growth and cloud condensation nucleus activity, Atmos. Chem. Phys., 7, 1961-1971, https://doi.org/10.5194/acp-7-1961-2007, 2007. 
Petters, M. D., Carrico, C. M., Kreidenweis, S. M., Prenni, A. J., DeMott, P. J., Collett Jr., J. L., and Moosmüller, H.: Cloud condensation nucleation activity of biomass burning aerosol, J. Geophys. Res.-Atmos., 114, D22205, https://doi.org/10.1029/2009JD012353, 2009.

Pöschl, U., Rose, D., and Andreae, M. O.: Climatologies of CloudRelated Aerosols - Part 2: Particle Hygroscopicity and Cloud Condensation Nucleus Activity, in: Clouds in the Perturbed Climate System: Their Relationship to Energy Balance, Atmospheric Dynamics, and Precipitation, 58-72, MIT Press, Cambridge, 2009.

Pringle, K. J., Tost, H., Pozzer, A., Pöschl, U., and Lelieveld, J.: Global distribution of the effective aerosol hygroscopicity parameter for CCN activation, Atmos. Chem. Phys., 10, 52415255, https://doi.org/10.5194/acp-10-5241-2010, 2010.

Psichoudaki, M., Nenes, A., Florou, K., Kaltsonoudis, C., and Pandis, S. N.: Hygroscopic properties of atmospheric particles emitted during wintertime biomass burning episodes in Athens, Atmos. Environ., 178, 66-72, https://doi.org/10.1016/j.atmosenv.2018.01.004, 2018.

Rajput, P., Mandaria, A., Kachawa, L., Singh, D. K., Singh, A. K., and Gupta, T.: Wintertime source-apportionment of $\mathrm{PM}_{1}$ from Kanpur in the Indo-Gangetic plain, Climatic Change, 1, 503507, 2015

Ram, K., Tripathi, S. N., Sarin, M. M., and Bhattu, D.: Primary and secondary aerosols from an urban site (Kanpur) in the Indo-Gangetic Plain: impact on $\mathrm{CCN}, \mathrm{CN}$ concentrations and optical properties, Atmos. Environ., 89, 655-663, https://doi.org/10.1016/j.atmosenv.2014.02.009, 2014.

Reddy, M. S. and Venkataraman, C.: Inventory of aerosol and sulphur dioxide emissions from India: I - Fossil fuel combustion, Atmos. Environ., 36, 677-697, https://doi.org/10.1016/S13522310(01)00463-0, 2002.

Rissler, J., Swietlicki, E., Zhou, J., Roberts, G., Andreae, M. O., Gatti, L. V., and Artaxo, P.: Physical properties of the submicrometer aerosol over the Amazon rain forest during the wetto-dry season transition - comparison of modeled and measured CCN concentrations, Atmos. Chem. Phys., 4, 2119-2143, https://doi.org/10.5194/acp-4-2119-2004, 2004.

Rose, D., Nowak, A., Achtert, P., Wiedensohler, A., Hu, M., Shao, M., Zhang, Y., Andreae, M. O., and Pöschl, U.: Cloud condensation nuclei in polluted air and biomass burning smoke near the mega-city Guangzhou, China - Part 1: Size-resolved measurements and implications for the modeling of aerosol particle hygroscopicity and CCN activity, Atmos. Chem. Phys., 10, 33653383, https://doi.org/10.5194/acp-10-3365-2010, 2010.

Rose, D., Gunthe, S. S., Su, H., Garland, R. M., Yang, H., Berghof, M., Cheng, Y. F., Wehner, B., Achtert, P., Nowak, A., Wiedensohler, A., Takegawa, N., Kondo, Y., Hu, M., Zhang, Y., Andreae, M. O., and Pöschl, U.: Cloud condensation nuclei in polluted air and biomass burning smoke near the megacity Guangzhou, China - Part 2: Size-resolved aerosol chemical composition, diurnal cycles, and externally mixed weakly CCN-active soot particles, Atmos. Chem. Phys., 11, 2817-2836, https://doi.org/10.5194/acp-11-2817-2011, 2011.

Rosenfeld, D.: TRMM observed first direct evidence of smoke from forest fires inhibiting rainfall, Geophys. Res. Lett., 26, 31053108, https://doi.org/10.1029/1999GL006066, 1999.
Rosenfeld, D.: Suppression of rain and snow by urban and industrial air pollution, Science, 287, 1793-1796, https://doi.org/10.1126/science.287.5459.1793, 2000.

Rosenfeld, D., Lahav, R., Khain, A., and Pinsky, M.: The role of sea spray in cleansing air pollution over ocean via cloud processes, Science, 297, 1667-1670, https://doi.org/10.1126/science.1073869, 2002.

Rosenfeld, D., Lohmann, U., Raga, G. B., O’Dowd, C. D., Kulmala, M., Fuzzi, S., Reissell, A., and Andreae, M. O.: Flood or drought: how do aerosols affect precipitation?, Science, 321, 1309-1313, https://doi.org/10.1126/science.1160606, 2008.

Roy, A., Chatterjee, A., Sarkar, C., Das, S. K., Ghosh, S. K., and Raha, S.: A study on aerosol-cloud condensation nuclei (CCN) activation over eastern Himalaya in India, Atmos. Res., 189, 6981, https://doi.org/10.1016/j.atmosres.2017.01.015, 2017.

Rudich, Y., Khersonsky, O., and Rosenfeld, D.: Treating clouds with a grain of salt, Geophys. Res. Lett., 29, 2060, https://doi.org/10.1029/2002GL016055, 2002.

Sandradewi, J., Prévôt, A. S. H., Szidat, S., Perron, N., Alfarra, M. R., Lanz, V. A., Weingartner, E., and Baltensperger, U.: Using Aerosol Light Absorption Measurements for the Quantitative Determination of Wood Burning and Traffic Emission Contributions to Particulate Matter, Environ. Sci. Technol., 42, 33163323, https://doi.org/10.1021/es702253m, 2008.

Seinfeld, J. H.: Atmospheric Chemistry and Physics of Air Pollution, Environ. Sci. Technol., 20, 863-863, https://doi.org/10.1021/es00151a602, 1986.

Sharma, S. K., Kumar, M., Gupta, N. C., Saxena, M., and Mandal, T. K.: Characteristics of ambient ammonia over Delhi, India, Meteorol. Atmos. Phys., 124, 67-82, https://doi.org/10.1007/s00703013-0299-8, 2014.

Squires, P.: The microstructure and colloidal stability of warm clouds: Part II - The causes of the variations in microstructure, Tellus, 10, 262-271, https://doi.org/10.1111/j.21533490.1958.tb02012.x, 1958.

Stelson, A. W. and Seinfeld, J. H.: Relative humidity and $\mathrm{pH}$ dependence of the vapor pressure of ammonium nitratenitric acid solutions at $25^{\circ} \mathrm{C}$, Atmos. Environ., 16, 993-1000, https://doi.org/10.1016/0004-6981(82)90185-8, 1982.

Sullivan, R. C., Moore, M. J. K., Petters, M. D., Kreidenweis, S. M., Roberts, G. C., and Prather, K. A.: Effect of chemical mixing state on the hygroscopicity and cloud nucleation properties of calcium mineral dust particles, Atmos. Chem. Phys., 9, 33033316, https://doi.org/10.5194/acp-9-3303-2009, 2009.

Tao, W. K., Chen, J. P., Li, Z., Wang, C., and Zhang, C.: Impact of aerosols on convective clouds and precipitation, Rev. Geophys., 50, RG2001, https://doi.org/10.1029/2011RG000369, 2012.

Tiwari, S., Dahiya, A., and Kumar, N.: Investigation into relationships among $\mathrm{NO}, \mathrm{NO}_{2}, \mathrm{NO}_{x}, \mathrm{O}_{3}$, and $\mathrm{CO}$ at an urban background site in Delhi, India, Atmos. Res., 157, 119-126, https://doi.org/10.1016/j.atmosres.2015.01.008, 2015.

Turšič, J., Podkrajšek, B., Grgić, I., Ctyroky, P., Berner, A., Dusek, U., and Hitzenberger, R.: Chemical composition and hygroscopic properties of size-segregated aerosol particles collected at the Adriatic coast of Slovenia, Chemosphere, 63, 1193-1202, https://doi.org/10.1016/j.chemosphere.2005.08.040, 2006.

Wang, J., Cubison, M. J., Aiken, A. C., Jimenez, J. L., and Collins, D. R.: The importance of aerosol mixing state and 
size-resolved composition on $\mathrm{CCN}$ concentration and the variation of the importance with atmospheric aging of aerosols, Atmos. Chem. Phys., 10, 7267-7283, https://doi.org/10.5194/acp10-7267-2010, 2010.

Wang, J. and Martin, S. T.: Satellite characterization of urban aerosols: Importance of including hygroscopicity and mixing state in the retrieval algorithms, J. Geophys. Res.-Atmos., 112, D17203, https://doi.org/10.1029/2006JD008078, 2007.

Wang, S., Nan, J., Shi, C., Fu, Q., Gao, S., Wang, D., Cui, H., SaizLopez, A., and Zhou, B.: Atmospheric ammonia and its impacts on regional air quality over the megacity of Shanghai, China, Sci. Rep.-UK, 5, 15842, https://doi.org/10.1038/srep15842, 2015.

Wang, Y. and Chen, Y.: Significant Climate Impact of Highly Hygroscopic Atmospheric Aerosols in Delhi, India, Geophys. Res. Lett., 46, 5535-5545, https://doi.org/10.1029/2019GL082339, 2019.
Wu, Z. J., Poulain, L., Henning, S., Dieckmann, K., Birmili, W., Merkel, M., van Pinxteren, D., Spindler, G., Müller, K., Stratmann, F., Herrmann, H., and Wiedensohler, A.: Relating particle hygroscopicity and $\mathrm{CCN}$ activity to chemical composition during the HCCT-2010 field campaign, Atmos. Chem. Phys., 13, 7983 7996, https://doi.org/10.5194/acp-13-7983-2013, 2013.

Zhang, Q., Jimenez, J. L., Worsnop, D. R., and Canagaratna, M.: A case study of urban particle acidity and its influence on secondary organic aerosol, Environ. Sci. Technol., 41, 3213-3219, https://doi.org/10.1021/es061812j, 2007. 